INTERNATIONAL JOURNAL OF SYSTEMATIC BACTERIOLOGY

Vol. 16, No. 3 July 1966 pp. 253-297

\title{
NEW SEROTYPES OF SALMONELLA IDENTIFIED \\ BEFORE 1964 AT THE SALMONELLA REFERENCE LABORATORY, COLINDALE
}

\author{
S. P. Lapage, Joan Taylor, C. R. Nicewonger \\ and A. G. Phillips
}

Salmonella Reference Laboratory, Colindale, London

SUMMARY. The antigenic structure, source and place of origin of 290 new Salmonella serotypes identified at the Salmonella Reference Laboratory, Colindale, are arranged alphabetically with available information on the first isolations.

\section{INTRODUCTION}

Two hundred and ninety new Salmonella serotypes identified at the Salmonella Reference Laboratory, Colindale, from 1945 to 1963 are given in the following list. They are arranged alphabetically. Their antigenic structure, source, geographical area of isolation, origin of the name and reference to the original isolation are given where these were available. The search for references ceased at the end of March, 1965.

The convention of Kauffmann (1961) has been followed by marking with an asterisk the serotypes belonging to subgenus II Kauffmann $(1960 \mathrm{~b}, 1963 \mathrm{a})$, e.g. *S. bleadon. The biochemical behaviour of the serotypes is not further discussed except in a few cases. Further information may be found in Kaufmann's publications.

Available information on additional isolations of new serotypes isolated up to 1951 are given in the list under the relevant serotype; after 1951, details of further isolations for all new serotypes identified at Colindale may be found in Taylor, Lapage, Brookes, King, Payne, Sandiford and Stevens on (1965).

All serotypes with the somatic antigenic structure 1,6, 14,25 have been represented in this manner. Earlier the formula was given as (1),6,14,25 but Kauffmann (1961b) omitted the brackets on the somatic antigen I writing the 
formula as $1,6,14,25$ with the comment

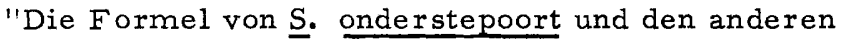
species der Gruppe H 2 war früher mit (1), 6, 14, 25 angegeben, da diese species nicht das ganze $\mathrm{O}$ l-Antigen enthalten. Da jedoch nähere Untersuchungen nicht bei allen derartigen species ausgeführt sind, so wurde die Klammer um das 1-Antigen fortgelas sen."

The antigenic structure given for each serotype is the one accepted at the present time. In some cases the structure of the original isolation was given a different formula, or the formula was written in a different way. In these instances references are given to the changes which have taken place.

The somatic antigens 36 and 37 are not given as they are not included in the Kauffmann White scheme at the present time.

The inclusion of an antigenic complex in square brackets, e.g. $[1,7]$ indicates that this phase may or may not be present in a given culture of the serotype.

\section{DISCUSSION}

This plethora of new types which we have identified at Colindale is typical of the discovery of large numbers of newly identified Salmonella serotypes in recent years, illustrated in Kelterborn (1961) and Professor Kauffmann's supplements to the Kauffmann White scheme (Kauffmann 1958b, $1959,1960 \mathrm{a}, 1961 \mathrm{a}, 1962,1963 \mathrm{~b}, 1964 \mathrm{a}, \mathrm{b})$.

The investigation of any previously unexplored geographical a rea or new biological material tends to yield previously undiscovered serotypes of Salmonella. Professor Collard isolated 46 new types in Nigeria between 1956 and 1958 and Professor Brede in South Africa 22 new types, of which 9 were from reptiles, between 1960 and 1963.

Kauffmann (1961b) on a theoretical basis, pointed out that approximately 20 different $\mathrm{H}$-complexes of phase I combined with approximately 10 different $H$-complexes of phase 2 might yield $200 \mathrm{H}$-combinations for each $\mathrm{O}-\mathrm{g}$ roup. With 50 O-groups we could obtain 10,000 possible Salmonella species. Since then the number of $O-g$ roups has been increased to approximately 60 and one new $\mathrm{H}$-antigen has been added. This gives a possible number of about 12,000 species. As 
Professor Kauffmann points out, this is a minimal number as the Kauffmann-White scheme is a simplified one. Whether all these combinations are genetically compatible and capable of existence in nature is unknown.

It is not possible to give an opinion on the occurrence and frequency of the evolution of the new Salmonella serotypes in nature. Mutation, transduction, recombination and genetic interchange between serotypes may be factors in the evolution of Salmonella. Hybridization with other groups of enterobacteria and the transfer of plasmids and episomes may also play a part.

A bacterial species is, presumably, kept stable by constant environmental pressure. It is possible that changes may occur under different natural conditions.

However, we think we can expect a steady rise throughout the years in the number of serotypes known to occur in nature, adding greatly to the number of serotypes known at present, which is as yet about a thousand.

\section{ACKNOW LEDGMENTS}

We wish to thank Professor F. Kauffmann for the confirmation of these cultures and for his advice and help throughout this period.

We wish to acknowledge the extensive help we have had in this laboratory from Miss S. Hilda Douglas, Miss Jennifer Stitt, Miss J. Waite, Miss M. Patricia Maltby and Mrs. Margaret $\mathrm{M}$. Brookes, who worked in the Department during the course of the years.

We also wish to thank Dr. G. J. G. King, Dr. D. J.H. Payne and Dr. B. R. Sandiford respectively of Bournemouth, Northallerton and Birmingham Regional Salmonella Centres, for preliminary identification of many of the strains from Wales and the south, north and middle of England.

We wish to thank the many colleagues, too numerous to mention, who sent us these cultures from many parts of the Commonwealth and kept us supplied with our material.

Finally we wish to thank Mrs. G. M. Moss without whom the manuscript would never have been typed or finished. 
LIST OF NEW SALMONELLA SEROTYPES IDENTIFIED AT THE SALMONELLA REFERENCE LABORATORY, COLINDALE

S.

$$
6,8: i: e, n, z_{15}
$$

Collard and Sen (1958b, 1960b)

Isolated from a Nigerian child with diarrhoea in $\mathrm{Aba}$, a town in

Nigeria. Received from Professor P. Collard, University of Ibadan, Nigeria in 1956.

S. abadina

28: $g, m: e, n, z_{15}$

Collard, Sen and Lapage (1962)

Isolated from the faeces of a European woman with dysentery. Abadina is a village in the precincts of University College, Ibadan, Nigeria. Received from Professor P. Collard, University of Ibadan, Nigeria in 1959.

S. accra $\quad 1,3,19: b: z_{6} \quad$ Hughes (1958)

The first isolation was from a patient in Accra, Ghana. Received from Captain J. Hunt, R.A.M.C., Accra, Ghana in 1955. The second isolation was from an African baby with diarrhoea. Received from Dr. M. H. Hughes, Medical Research Institute, Accra, Ghana in 1955.

S. adabraka $\quad 3,10: z_{4}, z_{23}:[1,7]$ Hughes (1958)

Isolated from a symptomless African adult in Adabraka, a suburb of Accra, Ghana, where the patient worked as a waiter. This culture was monophasic and had the antigenic structure $3,10: z_{4}, z_{23}$. Received from Dr. M. H. Hughes, Medical Research Instutute, Accra, Ghana in 1953. In 1961 a diphasic culture with the antigenic structure 3,10: $z_{4}, z_{23}: 1,7$ was identified. (Kauffmann 1962)

S. adamstown $28: k ; i, 6 \quad$ Harvey and Price (1962) Isolated from crushed Indian bone sampled in Adamstown, a district near the docks in Cardiff, South Wales. Received from Dr. R. W. S. Harvey, Public Health Laboratory, Cardiff in 1961.

S. adeoyo $16: \mathrm{g}, \mathrm{m} \quad$ Collard and Sen (1958b, 1960b) Isolated from an adult Nigerian with dysentery in Adeoyo, a district of Ibadan, Nigeria. Received from Professor P. Collard, University of Ibadan, Nigeria in 1956.

S. aderike $28: z_{38} \quad$ Collard, Sen and Lapage (1962) Isolated from the faeces of a patient and named after the patient. Received from Professor P. Collard, University of Ibadan, Nigeria in 1959.

S. africana 4,12:r(i):1,w Hughes (1958) Isolated from an African baby with diarrhoea in Ghana. The name is derived from "Africa". Received from Dr. M. H. Hughes, Medical Research Institute, Accra, Ghana in 1955. 
S. agama Collard and Montefiore (1956) Collard and Sen (1960b)

Isolated from the intestine of a lizard (Agama agama) in Nigeria. Received from Professor P. Collard, University of Ibadan, Nigeria in 1956.

S. agbeni Collard and Sen (1959, 1960b) Isolated from the faeces of a Nigerian child with diarrhoea. Named after the patient. Received from Professor P. Collard, University of Ibadan, Nigeria in 1957.

S. agodi $35: \mathrm{g}, \mathrm{t} \quad$ Collard and Sen (1958b, 1960b) Isolated from the faeces of a European adult with severe diarrhoea and vomiting in Agodi, a district of Ibadan. Recelved from Professor P. Collard, University of Ibadan, Nigeria in 1956.

S. ahmadi $\quad 1,3,19: \mathrm{d}: 1,5$

Isolated from human faeces in Ahmadi, which is one of the principal settlements in the Kuwait $0 i 1$ Company area, Kuwait. Received from Dr. J. Brebner, Kuwait 011 Company in 1959.

S. ajiobo $\quad 13,23: z_{4}, z_{23} \quad$ Collard, Sen and Montefiore (1957), Collard and Sen (1958b, 1960b)

Isolated from the faeces of a Nigerian child with diarrhoea and "enteric fever" in Ajiobo, a district in Ibadan. Received from Professor P. Collard, University of Ibadan, Nigeria in 1956.

S. akani i Collard and Sen $(1960 \mathrm{a}, \mathrm{b})$ Isolated from the faeces of a Nigerian child with diarrhoea. Named after the patient. Received from Professor P. Collard, University of Ibadan, Nigeria in 1958.

S. akuafo $16: y: 1,6 \quad$ Vella (1958)

Isolated from a lizard found in the precincts of Akuafo Hall, University of Ghana. Received from Major E. E. Vella, Military Hospital, Accra, Ghana in 1957.

S. alagbon Collard and Sen (1958b, 1960b) Isolated from cow faeces in Alagbon, a district of Ibadan. Received from Professor P. Collard, University of Ibadan, Nigeria in 1956.

S. albert 4,12: $z_{10}: e, n, x \quad$ M\&bius and Tauchnitz (1961) Isolated from water in the Albert Dock on the River Humber, Kingstonupon-Hul1. Received from Dr. J. H. McCoy, Public Health Laboratory, Kingston-upon-Hul1, Yorkshire,England, in 1960. The reference quoted is to a later isolation. 
S. amina collard and Sen (1960 a,b) Isolated from the faeces of a European aduit with dysentery. Named after "Amina Way", a street in the campus of University College, Ibadan. Received from Professor P. Collard, University of Ibadan, Nigeria, in 1958.

S. aminatu Collard and Sen (1960 a,b) Isolated from the blood of a Nigerian child with pyrexia. Named after the patient. Received from Professor P. Collard, University of Ibadan, Nigeria, in 1958.

s. amunigun Collard and Sen (1959, 1960b) Isolated from the faeces of a Nigerian adult with pyrexia, in Amunigun, a district of Ibadan, Nigeria. Received from Professor P. Collard, University of Ibadan, Nigeria, in 1957.

S. anfo $39: y: 1,2$ Report (1961) Isolated from protein concentrate meal, an animal feeding stuff, at Colindale, London, England. Name derived from ANimal FOod.Received from Dr. Betty C. Hobbs, Food Hygiene Laboratory, Colindale, in 1960.

S. ank $\quad 28: k: e, n, z_{15} \quad$ Collard and Sen (1959, 1960b)

Isolated from pus from the leg of an African female child with osteitis, in Nigeria. Received from Professor P. Collard, University of Ibadan, Nigeria, in 1957.

S. apapa Collard and Sen (1960a,b) Isolated from the faeces of a Nigerian adult with gastro-enteritis in Apapa, a district of Lagos, Nigeria. Received from Professor P. Collard, University of Ibadan, Nigeria in 1959.

s. aqua $30: k: 1,6$

Isolated from well water in Nairobi, Kenya. Name derived from Latin aqua (water). Received from Mr. J. St. A. M. D'Souza, Medical Research Laboratory, Nai robi, Kenya, in 1952.

S. ardwick $6,(7),(14): f, g$

isolated from pork sausage, the meat for which came from East Africa. The sausage was purchased in the Ardwick area of Manchester, England. This serotype was originally considered to have the antigenic structure $6,7: f, g$ and was found later to be $6,(7),(14): f, g$. Hofmann, Kauffmann and Anz (1960). Received from Dr. N. S. Mair, Public Heal th Laboratory, Manchester in 1952.

s. ayinde $\quad 4,12,27: d: z_{6} \quad$ Collard and Sen $(1960 a, b)$ Isolated from the faeces of a Nigerian child with diarrhoea. Named 
after the patient. Received from Professor.P. Collard, University of Ibadan, Nigeria in 1958.

S. bahati $\quad 13,22: b: e, n, z_{15}$ Isolated from a three-year-old boy with diarrhoea and vomiting for six months. Bahati is an area of Nairobi, Kenya. Received from Mrs. E. Watkins, Medical Research Laboratory, Nairobi in 1960.

S. baildon (9), 46:a:e, $n, x$ isolated from the faeces of two women aged 53 and 80,1 iving in the Bradford area of Yorkshire. No relationship could be demonstrated between the patients. Baildon is a small Yorkshire town, close to Bradford, England. Received from Dr. H. G. Smith, Public Health Laboratory, Bradford in 1957.

S. bamboye (9),46:b:1,w Isolated in England from egusi nut imported from West Africa. Named after a Nigerian technician working in the department where it was isolated. Received from Dr. Betty C. Hobbs, Food Hygiene Laboratory, Colindale, London, England in 1961.

*S. bechuana $\quad 4,12,27: 9, t$

Isolated in London from Bechuanaland boneless beef sampled in London. Received from Dr. Betty C. Mobbs, Food Hygiene Laboratory, Colindale, London, England in 1960.

5. bedford $\quad 1,3,19: 1, z_{13}, z_{28}: e, n, z_{15}$ Isolated from sewage in Bedford, a county town in England. Received from Dr. W. F. Lane, Public Health Laboratory, Bedford in 1961.

*S. bellville $16: e, n, x: 1,7 \quad$ Brede $(1961 \mathrm{c}, e)$

isolated from the faeces of a ten-year-old European boy from the neighbourhood of Stellenbosch University and Karl Bremer Hospital, Bellville, South Africa. Received from Professor H. D. Brede, Stellenbosch University in 1960.

S. bere $\quad 47: z_{4}, z_{23}: z_{6} \quad$ Collard and Sen (1958b, 1960b) Isolated from the faeces of a Nigerian adult with dysentery in Bere, the district of origin in Nigeria. Received from Professor P. Collard, University of Ibadan, Nigeria, in 1956.

S. birkenhead $6,7: c: 1,6 \quad$ Taylor and Douglas (1948) Nine strains were isolated from patients living in different parts of England. The first isolation was in Birkenhead, a town in Cheshire, near Liverpool, England. Received from Dr. Hugh Smith, General Hospital, Birkenhead, in 1947. 
s. birmingham $\quad 3,10: \mathrm{d}: 1, \mathrm{w}$

Isolated from sausage meat made in Nottingham, England. Named after the laboratory in Birmingham, England. Received from Dr. P. M. Congdon, Public Health Laboratory, Birmingham, in 1958.

* $\underline{\text {. }}$ bleadon

$$
\begin{aligned}
\text { 17: (f), g, } t:\left[e, n, x, z_{15}\right] & \text { Boycott, Taylor and Douglas } \\
& (1953), \text { Douglas and Taylor } \\
& (1954)
\end{aligned}
$$

Isolated from a tortoise in Bleadon, a suburb of Weston-super-Mare, Somerset. This culture was monophasic and had the antigenic structure 17:(f),g,t. Received from Dr. J. A. Boycott, Public Health Laboratory, Taunton, Somerset, England, in 1951. A diphasic strain with the antigenic structure $17:(f), g, t: e, n, x, z_{15}$ was isolated from a patient in Kuwait. Received from Dr. J. Brebner, Kuwait 011 Company, in 1962.

* . bloemfontein $6,7: b:[e, n, x]: z_{42}$

Isolated in England from imported south African frozen egg. This culture was diphasic and had the antigenic structure $6,7: b: z_{42}$. Received from Dr. W. H. H. Merivale, Guy's Hospital, London, England, in 1957. A further strain of human origin was isolated in

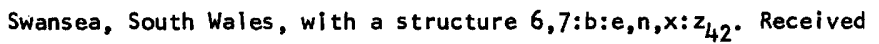
from Dr. G. J. G. King, Public Health Laboratory, Bournemouth, England, in 1963.

s. bokanjac $\quad 28: b: 1,7$ Isolated from three tortoises from Bokanjac, a village in Yugoslavia. Received from Dr. J. A. Boycott, Public Health Laboratory, Taunton, Somerset, England, in 1959.

s. bolton $\quad 3,10: y: e, n, z_{15} \quad$ Greenwood, Powis, Douglas and Taylor (1953)

Isolated from an adult with an exacerbation of long standing chronic colitis in Bolton, Lancashire, England. Received from Dr. E. Greenwood, Royal Infirmary, Bolton, in 1951.

S. bootle 47:k:1,5 Isolated from imported Ceylonese desiccated coconut in Bootle, a suburb of Liverpool, England. Received from Dr. E. C. Armstrong, Public Heal th Laboratory, Liverpool, in 1960.

S. bracknell 13,23:b:1,6

The first isolation was from human faeces in Preston, Lancashire, England. Received from Dr. A. A. Miller, Royal Infirmary, Preston, in 1953. The second isolation was from a stream in Bracknell, 
Berkshire, England. Received from Dr. N. Wood, Public Health Laboratory, Reading, Berkshire, in 1953.

S. bradford $\quad 4,12,27: r: 1,5$

Isolated from an adult female symptomless excretor in Bradford, Yorkshire, England. This culture had the antigenic structure 4, 12:

$r: 1,5$. Received from Dr. H. G. Smith, Public Health Laboratory, Bradford, in 1953. A later isolation, received from Professor P. Collard, University College, Ibadan, Nigeria, in 1958 had the antigenic structure $4,12,27: r: 1,5$.

S. brancaster $\quad 1,4,12,27: z_{29} \quad$ MacDonald, Sivell, Emms and Douglas (1948)

Isolated from mussels from Brancaster Staithe, on the east coast of England. It was later isolated from a dead turkey. The original isolation had the antigenic structure 1,4,12: $z_{29}$. Received from Dr. A. MacDonald, Public Health Laboratory, Norwich, England, in 1947. A later isolation had the antigenic structure $1,4,12,27: z_{29}$, Kauffmann (1959, 1960a).

S. brijbhumi Sharma and Singh (1963) Isolated from sewage in Brijbhumi, a city in Uttar Pradesh Province, India. Received from Dr. C. M. Singh, U. P. College of Veterinary Science, Mathura, India, in 1962.

S. bristol 13,22:z:1,7

Isolated from an adult male with severe enteritis in Bristol, a city in England. Received from Professor K. E. Cooper, University of Bristol, in 1952.

S. broughton $1,3,19: b: 1, w$ Isolated from a four-month-old child who was living in Broughton, a small town in Lancashire, England. Received from Dr. R. Gillett, Hope Hospital, Salford, Lancashire, in 1961.

S. brunei $\quad(8), 20: y: 1,5$

isolated from a five-month-old male child with pyrexia and diarrhoea, in Kuala Belait, Brunei. Received in 1958 from Dr. H. B. May, The London Hospital, London, England, who received the strain from North Borneo.

S. bukuru $6,8: b: 1, w \quad$ Collard and Sen $(1959,1960 \mathrm{~b})$ Isolated from a dead guinea pig. The culture originated in Bukuru, a town in Nigeria. Received from Professor $P$. Collard, University of Ibadan, Nigeria, in 1957. 
S. bury 4,12,27:c:z6 Stitt and Walsh (1956) Isolated from a child with acute respiratory infection and mild diarrhoea. Bury, North Lancashire, England, was the nearest large town to where the child lived. Received from Mr. T. Walsh, Booth General Hospital, Manchester, in 1953.

S. buzu $\quad 1,6,14,25: \mathrm{i}: 1,7$ Hughes (1958)

Isolated from an African patient. Buzu was the tribal name of the patient. Received from Dr. M. H. Hughes, Medical Research Institute, Accra, Ghana, in 1964.

S. calabar _... 1,3,19:e,h:l,w

Isolated in London from an adult male with gastro-enteritis who was working in Calabar, a town on the coast in Nigeria, at the time he contracted the illness. Received from Dr. D. Ridley, Hospjtal for Tropical Diseases, London, England, in 1962.

*s. caledon $\quad 4,12: g, m: e, n, x \quad$ Brede (1962a) Isolated in Caledon, a town in the Orange Free State, from a 58-yearold South African woman of the European ethnic group, with total epilation and eosinophilia, the symptoms suggesting arsenic poisoning. Received from Professor H. D. Brede, Stel lenbosch University, Bellville C. P., South Africa, in 1962.

*S. calvinia $\quad 6,7: a: z_{42} \quad$ Brede (1963a) I solated from a tortoise (Chersina angulata) caught on the highland of Calvinia, 400 kilometres north of Cape Town, South Africa. It was also isolated from the blood of three patients, with a clinical condition resembling S. paratyphi $C$ infection. Received from Professor H. D. Brede, Stellenbosch University. South Africa in 1962.

S. cambridge $\quad 3,15: \mathrm{e}, \mathrm{h}: \mathrm{l}, \mathrm{w} \quad$ Wilson, Taylor and Anderson (1947)

Isolated from an eighteen-year-old R.A.F. cadet with mild gastrointestinal symptoms and $\underline{S h}$. sonnei infection as well. Received from Dr. M. M. Wilson, Department of Pathology, Cambridge, England in 1945.

S. carno $\quad 1,3,19: 2: 1, w \quad$ Report (1959)

Isolated from meat and bone meal. Name derived from Latin caro, carnis flesh. Received from Dr. H. C. Walker, Public Health Laboratory, Maidstone, England in 1957.

*s. ceres $28: z: z_{39} \quad$ Brede (1962c) I solated from a 59-year-old Cape coloured woman from Ceres, a small town north of Cape Town, South Africa. Received from Professor H. D. Brede, Stellenbosch University, Bellville, C.P., South Africa in 1961. 
S. cayco $\quad$ (9) $, 46: k: z_{35}$

Isolated from Ceylonese desiccated coconut. The name is a compound name, i.e. CEYlonese Coconut. Received from Dr. Betty C. Hobbs, Food Hygiene Laboratory, Colindale, London, England in 1960.

s. chailey $\quad 6,8: z_{4}, z_{23}:\left[e, n, z_{15}\right]$ Isolated from the faeces of a 13-year-old girl with mild diarrhoea, who was in Karachi a few months prior to being in hospital at Chailey, a small town in Sussex, England. This culture was monophasic and had the antigenic structure $6,8: z_{4} z_{23}$. Received from Dr. J. E. Jameson, Public Health Laboratory, Brighton, Sussex, England, in 1951. In 1958 Professor Kauffmann received a culture of $S$. chailey with the antigenic structure $6,8: z_{4}, z_{23}: e, n, z_{15}$ (Kauffmann 1959).

S. charity $\quad 1,6,14,25: d: e, n, x$ Isolated from a tortoise and named after one of the virtues. Received from Dr. J. A. Boycott, Public Health Laboratory, Taunton, Somerset, England, in 1953.

*S. chersina

$$
\text { 47:z: } z_{6} \quad \text { Brede (1964b) }
$$

Isolated from a tortoise (Chersina angulata) in Klapmuts, South Africa. Named after the generic name of the tortoise. Received from Professor H. D. Brede, Stel lenbosch University, Bellville, C.P., South Africa, in 1962.

S. chincol $\quad 6,8: g, m, s: e, n, x$ Isolated from chinese frozen whole egg. The name is a compound name from $\mathrm{CH}$ INese egg, COLindale. Received from Dr. Betty C. Hobbs, Food Hygiene Laboratory, Colindale, London, England, in 1961.

5. chingola $\quad 11: \mathrm{e}, \mathrm{h:1,2}$ Douglas, Taylor and Fairchild (1953)

Isolated from an African woman with gastro-enteritis. Chingola is the name of a town in Zambia. Received from Mr. L. G. Fairchild, European Hospital, Chingola, Zambia, in 1949

*5. chinovum 42:b: 1,5 Isolated from Chinese frozen whole egg. The name is a compound name from CHINese egg(OVUM). Received from Dr. Betty C. Hobbs, Food Hygiene Laboratory, Colindale, England, in 1956.

s. chittagong (1),3,10,(19):b:2 35 Taylor, Hayes, Freeman and Anderson (1948)

Isolated from a West African adult cook in Chittagong. Pakisten, who was excreting the organism. Dr. P. R. Edwards found this serotype in snakes about the same time. Received from Dr. J. A. Boycott, 
South-east As ia Command, in 1946.

S. christiansborg $44: z_{4}, z_{24} \quad$ Hughes $(1955,1958)$

Isolated from the urine of a patient. Christiansborg is an old Danish palace in Accra, formerly the Governor's residence. Received from Dr. M. H. Hughes, Medical Research Institute, Accra, Ghana, in 1954.

*S. chudleigh $\quad 3,10: e, n, x: 1,7$

Isolated from sewage from a pumping station in Chudleigh, a town in Devonshire, England. Received from Dr. B. Moore, Public Health Laboratory, Exeter, Devon, in 1961.

S. clerkenwell $\quad 3,10: z: 1, w \quad$ Story, Douglas and Taylor

Isolated from a three-month-old girl with gastro-enteritis in Clerkenwell, a district of London, England. The mother was also infected. Received from Dr. P. Story, St. Bartholomew's Hospital, London, in 1950.

*E. . clifton Douglas and Taylor (1954) Isolated from a tortoise in the Zoological Gardens, situated in Clifton, a suburb of Bristol. Received from Professor K. E. Cooper, Bristol University, England, in 1961.

S. coleypark 6,7:a:1,w

Isolated from chicks. Named after the site of the Veterinary Investigation Centre, Coleypark, Reading, Berkshire, England. Received from Mr. R. H. Loosemore, Veterinary Investigation Centre, Reading, in 1960.

S. colindale 6,7:r:1.7 Price and Holt (1955) Isolated from an air stewardess, aged 27, with gastro-enteritis, twenty-four hours after she had arrived in London from Nigeria. She had stopped at several places en route. The culture was isolated by Dr. H. D. Holt, Diagnostic Reference Laboratory, Colindale, London, England, in 1951 .

S. demerara $\quad 13,23: z_{10}: 1, w$ Isolated from a 40-year old African male, who was operated on for appendicitis and relief of intestinal obstruction, and who died after the operation. Named after a town in British Guiana. Received from Dr. B. B. G. Nehaul, Central Medical Laboratory, Demerara, British Guiana, in 1959. 
S. deversoir $\quad 45: c: e, n, x \quad$ Watkins, Douglas and Taylor

(1955)

Isolated from a food handler at Fayid, Egypt. Deversoir is a small village in Egypt. Received from Captain J. F. Watkins, War Office Investigation Team, Fayid, Egypt, in 1951.

S. driffield $\quad 1,40: d: 1,5$

Isolated from sewage polluted Driffield Canal which is in the region of Kingston-upon-Hull, Yorkshire, England. Received from Dr. J. H. McCoy, Public Health Laboratory, Kingston-upon-Hull, in 1960.

S. drypool $\quad 3,15: \mathrm{g}, \mathrm{m,s}$ Isolated from the sewage-polluted river Drypool at Kingston-upon-Hull, Yorkshire, England. Received from Or. J. H. McCoy, Public Health Laboratory, Kingston-upon-Hull, Yorkshire in 1960.

S. dugbe 45:d:1,6 Collard and Sen (1960b) Isolated from meat sold in Dugbe Market, Ibadan, Nigeria. Received from Professor P. Collard, University College, Ibadan, Nigeria, in 1956.

*S. duivenhoks $\quad(9), 46: g, m, s, t: e, n, x$

Isolated from a tortoise in South Africa. Received from Professor H. D. Brede, Stellenbosch University, Bellville, C.P., South Africa, in 1963.

S. durham 13,23:b:e,n, $z_{15}$ Isolated from a man with pyrexia and diarrhoea in Durham, a county town in England. Received from Dr. J. E. Ennis, Pathology Department, Dryburn Hospital, Durham, England, In 1954.

s. ealing $\quad 35: \mathrm{g}, \mathrm{m}, \mathrm{s}$

Isolated from an infant boy at Elfin Grove Nursery, Ealing, a borough of London, England. Isolated by Miss M. Patricia Maltby, Salmonella Reference Laboratory, Colindale, London, in 1959.

S. edmonton $\quad 6,8: 1, v: e, n, z_{15}$

Isolated from a patient in Edmonton, a borough of London, England. Received from Dr. M. E. Mair Thomas, Public Health Laboratory, Edmonton, in 1954.

S. egusi $\quad 41: d$ Isolated from ground egusi nut, inported from West Africa. Received from Dr. Betty C. Hobbs, Food Hygiene Laboratory, Colindale, London, England, in 1962.

s. egusitoo $\quad 1,42: b: z_{6}$ Isolated from dried egusi nut, imported from West Africa. A compound 
name EGUSI TOO i.e.-(from egusi nut also). Received from Dr. Betty c. Hobbs, Food Hygiene Laboratory, Colindale, London, England, in 1962.

S. ekotedo (9) $46: z_{4}, z_{23} \quad$ Collard and Sen $(1959,1960 \mathrm{~b})$ Isolated from the faeces of a Nigerian child with dysentery, in Ekotedo, a district of Ibadan, Nigeria. Received from Professor P. Collard, University College, Ibadan, Nigeria, in 1957.

*s. elsiesrivier $16: z_{42}: 1,6 \quad$ Brede (1962b) isolated from a four-month-old Cape coloured (suckling) child with diarrhoea, who was born in Elsiesrivier, a suburb of Cape Town, South Africa. Received from Professor H. D. Brede, Stellenbosch University, Beliville, C.P., South Africa, in 1961.

S. entebbe $\quad 1,4,12,27: z: z_{6} \quad$ McAnulty (1958)

Isolated from Zebu cattle in Uganda, and named after a town in Uganda, Entebbe, which is the site of the laboratory. Received from Mr. E. McAnulty, Animal Health Research Centre, Entebbe, Uganda, in 1955.

S. epicrates $\quad 3,10: b: 1, w$

Isolated from a rainbow boa (Epicrates cenchris) in Bristol 200 and named after the generic name of the snake. Received from Dr. A. H. Linton, University of Bristol, England, in 1957.

S. fallowfield $\quad 3,10: 1, z_{13}, z_{28}: e, n, z_{15}$ Isolated from a 35-year-old man living in Fallowfield, a suburb of Manchester. Received from Dr. M. T. Parker, Public Health Laboratory, Manchester, England, in 1960.

S. fanti $\quad 13,23: z_{38} \quad$ Hughes (1958)

Isolated from the faeces of a male African. Fanti is the tribal name of the patient who came from the Accra area, Ghana. Received from Dr. M. H. Hughes, Medical Research Institute, Accra, Ghana, in 1954.

S. fayed $6,8: 1, w: 1,2 \quad$ Anderson, Anderson and Taylor (1947)

Isolated from the blood culture of a German prisoner of war at Fayed, Egypt, who was suffering from enteritis followed by bacterial endocarditis. The patient died. Received from Dr. H. J. Anderson, 19th General Hospital, M.E.F., in 1945.

S. ferlac $\quad 1,6,14,25: a: e, n, x$

Isolated from Ceylonese desiccated coconut. Compound name from FERments LACtose since this serotype ferments lactose. Received from Dr. Betty C. Hobbs, Food Hygiene Laboratory, Colindale, London, England, in 1960 . 
*.s. finchley $\quad 3,10: z: e, n, x$

Isolated from Argentine horsemeat in Finchley, a borough of London. Received from Dr. C. E. D. Taylor, Diagnostic Reference Laboratory, Colindale, England, in 1961.

s. fortune $\quad 4,12,27: z_{10}: z_{6}$

Isolated from sewage and given the name of "fortune". Received from Dr. J. H. C. Walker, Public Health Laboratory, Maidstone, England, in 1956.

S. freetown $38: y: 1,5$ Reid, Stitt and Taylor (1956) Isolated from a seven-month-old African baby with fever and diarrhoea for three weeks, who died soon after. Freetown is the capital of Sierra Leone where the Government Laboratory is situated. Received from Dr. J. D. Reid, Government Laboratory, Freetown, Sierra Leone, in 1952.

S. gambia $35: i: e, n, z_{15}$ Isolated in Gambia from a pig dying of gastro-enteritis. Received from Mr. G. J. Knight, Department of Veterinary Services, Abuko, Gambia, in 1953.

S. garba Collard and Sen $(1960 a, b)$ Isolated from guinea pig faeces. Garba is the district of origin in Nigeria. Received from Professor P. Collard, University College, Ibadan, Nigeria, in 1959.

S. gateshead $\quad(9), 46: 9,5, t$ Isolated from an eight-month-old boy, living in South Shields. Gateshead where the Laboratory was situated, is a town in the county of Durham, England. Received from Dr. R. Norton, Publlc Health Laboratory, Newcast le-on-Tyne, Durham, in 1961.

S. gege $30: r: 1,5$ Collard and Sen $(1960 a, b)$ Isolated from the faeces of a Nigerian child with diarrhoea in Gege, a district of Ibadan, Nigeria. Received from Professor P. Collard, University College, Ibadan, Nigeria, in 1958.

S. ghana $21: b: 1,6 \quad V e l l a(1958)$ Isolated in Ghana from a lizard. Received from Major E. E. Vella, Military Hospital, Accra, Ghana, in 1957.

*S. gilbert $\quad 6,7: z_{39}: 1,7$ Isolated from South African frozen egg. Named after W. S. Gilbert, an English poet and librettist (see $\underline{S}$. sullivan). Received from or. W. H. H. Merivale, Guy's Hospital, London, England in 1960. 
s. glas gow

$16: b: 1,6$

Browning, Moore and

Stevenson (1959)

I solated in Glasgow from a five-month-old boy with diarrhoea.

Glasgow is a city in Scotland. Received from Dr. P.M.H. Browning, Bacteriological Service Laboratories, Glasgow, in 1957.

s. gloucester $\quad 1,4,12,(27): i: 1, w \quad W a i t e$, Taylor and Davey

(1957)

Isolated from five people and a processed meat food. It was a hospital cross-infection which involved three and possibly more of the patients. There were cases of severe gastro-enteritis and two symptomless infections. Gloucester is the county town of Gloucestershire in England. The antigen 27 is given in round brackets as it is not fully developed. Waite, Taylor and Davey (1957). Received from Dr. E. N. Davey, Gloucestershire Royal Hospital, Gloucester in 1954.

S. gokul $\quad 1,51: \mathrm{d}$ Datta and Singh (1964)

Isolated from a pig in Gokul, a town in India. Received from Dr.

C. M. Singh, U.P. College of Veterinary Science, Mathura, India, in 1963.

S. gold-coast $6,8: r: 1, w \quad$ Hughes (1958)

Isolated from the caecal contents of an African child with fever and diarrhoea and a retrocaecal abscess. The child died. Isolated in the Gold Coast, a former British colony now called Ghana. Received from Dr. M. H. Hughes, Medical Research Institute, Accra, Ghana, in 1953.

S. good 21:f,g:e,n,x

Isolated from Argentine horsemeat. Mr. Good was the name of the inspector who sent the meat from the port of London. Received from Dr. Betty C. Hobbs, Food Hygiene Laboratory, Colindale, London, England in 1963.

*S. grabouw $11: \mathrm{g}, \mathrm{m}, \mathrm{s}, \mathrm{t}: \mathrm{z}_{39}$ Brede (1964a)

Isolated from a 21-year-old European nurse with diarrhoea in the village of Grabouw, east of Cape Town, South Africa. Received from Professor H. D. Brede, Stellenbosch University, Belliville, C.P., South Africa, in 1962.

*S. grunty $\quad 1,40: z_{39}: 1,6$

Isolated from sausages. The name is a local, English, rural name for cowdung. This serotype produced $\beta-g a l a c t o s i d a s e$ and failed to ferment dulcitol. It was classified as a member of the Salmonella 
rather than the Arizona Group. Received from Dr. J. H. Tomlinson, Public Health Laboratory, County Hall, London, England, in 1961.

s. guinea Hughes (1958)

Isolated from a European baby convalescent from Salmonella saint paul infection. Isolated in the Gulf of Guinea, a general term for the West African coast. Received from Dr. M. H. Hughes, Medical Research Institute, Accra, Ghana, in 1955.

S. guildford 28:k:1,2 Report (1959)

Isolated from meat and bone meal. Guildford is the county town of Surrey, England. Received from Dr. H. D. S. Morgan, Public Health Laboratory, Guildford, in 1957.

S. gwoza $\quad 1,3,19: a: e, n, z_{15}$ Collard and Sen (1959, (1960b)

Isolated from the intestine of a lizard (Agama agama) in Gwoza, a town in Northern Nigeria. Received from Professor P. Collard, University College, Ibadan, Nigeria, in 1958.

*S. heilbron $6,7: 1, z_{28}: 1,5:\left[z_{42}\right]$

Isolated from eleven separate batches of South African egg. Heilbron is a town in South Africa from the region of which the eggs came. This strain was diphasic and had the antigenic structure of 6,7: $1, z_{28}: 1,5$. Received from Dr. W. H. H. Merivale, Guy's Hospital, London, England in 1959. A further isolation from a snake in South Africa in 1964 was triphasic and had the antigenic structure 6,7: $1, z_{28}: 1,5: z_{42}$. Received from Professor H. D. Brede, Stellenbosch University, South Africa, in 1964.

S. heron $16: a: z_{6}$

Isolated from a tortoise found by Mrs. Heron. The name of the village from which it came was too difficult to pronounce for scientific usage. Received from Dr. J. A. Boycott, Public Health Laboratory, Taunton, Somerset, England, in 1962.

S. hillsborough $\quad 6,7: z_{41}: 1, w$ Isolated from two brothers aged 7 and 12, convalescent from Sh. sonnei infection, living in Hillsborough, a suburb of Sheffield, Yorkshire, England. Received from Dr. E. H. Gillespie, Public Health Laboratory, Sheffield in 1959.

5. honelis 28:a:e, $n, z_{15}$ Isolated from a Honel is Chameleon in the London Zoo. Name derived from that of the chameleon. Received from Dr. R. N. F. Fiennes of the London Zoo, England, in 1963. 
s. horsham $\quad 1,6,14,25: 1, v: e, n, x$

Isolated from dried egg. Horsham is a town in Sussex, England.

Received from Dr. L. Foulds, Emergency Public Health Laboratory, Horsham, Sussex, in 1944.

s. hull

$16: b: 1,2$

Alexander, Douglas and Taylor

Isolated from an undernourished two-month-old baby boy with diarrhoea and vomiting. The baby died 21 days later. Hull is a town in Yorkshire, England. Received from Dr. J. G. Alexander, Western General Hospital, Hul1, in 1951.

*S. humber $53: z_{4}, z_{24}$ Isolated from dock water in the sewage polluted estuary of the River Humber. Received from Dr. J. H. McCoy, Public Health Laboratory, Kingston-upon-Hul1, Yorkshire, England, in 1959.

S. Ibadan 13,22:b:1,5 Stevenson (1953), Collard and Sen (1958a, 1960b)

Isolated from the faeces of an African adult. $\underline{S}$. typhi previously had been isolated from the same patient, who died of yellow fever. Ibadan is the capital of West Nigeria. Received from Dr. W. D. Silvera, Adeoyo Hospital, Ibadan, Nigeria, in 1962.

S. Idikan 13,23:i: 1,5

Isolated from a woman with acute gastro-enteritis, who lived in Idikan, a district of Ibadan, Nigeria. Received from Dr. F. Saliba, Adeoyo Hospital, Ibadan, Nigeria, in 1958.

S. ilala 28:k:1,5 Mackey (1955)

Isolated from an African baby with enteritis in llala, a district near Dar-es-Salaam, Tanganyika. Received from Dr. J. Mackey, Medical Laboratory, Dar-es-Salaam, Tanzania, in 1952.

s. ilugun $\quad(1), 3,10,(19): z_{4}, z_{23}: z_{6}$

Isolated from an African with diarrhoea. Ilugun is a town in

Western Nigeria. Received from Professor P. Collard, University College, Ibadan, Nigeria, in 1957.

S. inpraw $\quad 41: z_{10}: e, n, x$

Isolated from raw Indian prawns. Compound name derived from INdian

PRAWns. Received from Dr. Betty C. Hobbs, Food Hygiene Laboratory, Colindale, London, England, in 1962. 
S. ipswich $\quad 41: z_{4}, z_{24}$

Isolated from bone meal. Ipswich is the county town of Suffolk,

England. Received from Dr. J. M. S. Dixon, Public Health Laboratory, Ipswich, in 1958.

*is. is lington $\quad 3,10: 9, t$

Isolated from pet meat in Islington, a borough of London, England.

Received from Dr. C. E. D. Taylor, Diagnostic Laboratory, Collindale, London, in 1961.

s. isuge $13,23: d: z_{6}$

Isolated from egusi nut. The name is the reverse spelling of EGUSI=

ISUGE. Received from Dr. Betty C. Hobbs, Food Hyglene Laboratory, Colindale, London, in 1962.

$\begin{array}{lll}\text { S. itutaba } & (9), 46: c: z_{6} & \begin{array}{l}\text { Collard and Sen (1959, } \\ \text { 1960b) }\end{array}\end{array}$

Isolated from the faeces of a Nigerian boy with diarrhoea. Received from Professor P. Collard, University College, Ibadan, Nigeria in 1957.

S. Laja $\quad 4,12,27: z_{4}, z_{23}$ Collard and Sen $(1960 a, b)$ Isolated from the faeces of a European adult with diarrhoea. Named after a street in the campus of University College, Ibadan, Nigeria. Jaja is the name of a famous Nigerian royal personage. Received from Professor P. Collard, University College, Ibadan, Nigeria, in 1958.

S. Lamaica 9,12:r:1,5 Grant (1958)

Isolated in Jamaica from the faeces of a nine-year-old girl with

gastro-enteritis. Received from Dr. L. S. Grant, University College of the West Indies, Jamaica, in 1956.

S. Langwani 17:a:1,5 Mackey (1955) Isolated from a patient with food poisoning in Jangwani, a small district near Dar-es-Salaam, Tanganyika. Received from Dr. J. Mackey, Medical Laboratory, Dar-es-Salaam, Tanzania, in 1952.

S. jedburgh $3,10: z_{29}$ Report (1959) Isolated from meat and bone meal bought in Jedburgh, Roxburghshire, Scotland. Received from Dr. R. Norton, Public Health Laboratory, Newcastle-on-Tyne, England, in 1957.

s. Lericho $\quad 1,4,12,27: c: e, n, z_{15} \begin{aligned} & \text { Collard and Sen (1959, } \\ & 1960 b)\end{aligned}$

Isolated from the faeces of a European child with enteritis. 
Jericho is the name of a hospital in Ibadan, Nigeria. Received from Professor P. Collard, University College, Ibadan, Nigeria, in 1957.

S. jodhpur Harvey and Price (1962) Isolated from Indian crushed bone from Jodhpur, India. Received from Dr. R. W. S. Harvey, Public Health Laboratory, Cardiff, South Wales, in 1958.

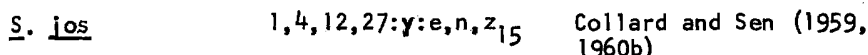

Isolated from the faeces and mesenteric glands of a cat. Jos is a town in Northern Nigeria. Received from Professor P. Collard, University College, Ibadan, Nigeria, in 1957.

S. jukestown 13,23:i:e,n, $z_{15}$ of human origin in Beterverwagting, British Guiana. The name was considered to be too clumsy for scientific use and jukestown was substituted. Received from.Dr. J. Morrison Ritchie, Typhoid Research Laboratory, Georgetown, British Guiana, in 1961.

S. kaduna $\quad 6,(7),\left(14: c: e, n, z_{15} \quad \begin{array}{l}\text { Collard and Sen (1958, } \\ 1960 b)\end{array}\right.$, Isolated from the faeces of a European sergeant with gastro-enteritis at the Military Hospital, Kaduna, the capital of Northern Nigeria. The original structure was given as $6,7: c: e, n, z_{15}$ but later was found to be 6, (7), (14):c:e,n, $z_{15}$ (Hofmann, Kauffmann and Anz, 1960). Received from Major J. C. Crook, David Bruce Laboratories, East Everleigh, Wiltshire, England, in 1953.

S. kaitaan $\quad 1,6,14,25: \mathrm{m}, \mathrm{t}$ isolated from Chinese frozen whole egg. Kaitaan is reputed to be a Chinese word for egg. Received from Dr. Betty C. Hobbs, Food Hygiene Laboratory, Colindale, London, England, in 1962.

s. kamory 4,12,27:y:z $6 \quad$ Collard and Sen (1960a, b) Isolated from the faeces of a Nigerian child with diarrhoea. Received from Professor P. Collard, University College, Ibadan, Nigeria, in 1958 .

S. kampala $1,42: c: z_{6} \quad$ McAnulty (1958) Isolated from Zebu cattle faeces in Kampala, a town in Uganda. Received from Mr. E. McAnulty, Animal Health Research Center, Entebbe, Uganda, in 1956. 
S. kandla Harvey and Price (1962) Isolated from Indian bone chips from Kandla, a town in India. Received from Dr. R. W. S. Harvey, Public Health Laboratory, Cardiff, South Wales, in 1958.

s. kaneshie $\quad 1,42: \mathrm{i}: 1, \mathrm{w} \quad$ Hughes (1958)

Isolated from an undernourished baby with diarrhoea. Kaneshie is a suburb of Accra, Ghana. Received from Dr. M.H. Hughes, Medical Research Institute, Accra, Ghana, in 1954.

S. karachi 45:d:e,n,x Harvey and Price (1962) Isolated from Indian bone chips. Karachi is a town in Pakistan. Received from Dr. R. W. S. Harvey, Public Health Laboratory, Cardiff, South Wales, in 1958.

S. karamoja 40: $z_{41}: 1,2 \quad$ McAnulty (1958) Isolated from Zebu cattle faeces in the abattoir in Kampala, the capital of Uganda. Karamoja is a district in the North-East of Uganda. Received from Mr. E. McAnulty, Animal Health Research Centre, Entebbe, Uganda, in 1956.

*S. katesgrove $\quad 1,13,23: \mathrm{m}, \mathrm{t}: 1,5$

Isolated from Bechuanaland boneless beef held in an abattoir near Katesgrove, a district of Reading, Berkshire, England. Received from Dr. N. Wood, Public Health Laboratory, Reading, in 1961.

S. kenya $\quad 6,7: 1, z_{13}: e, n, x$ Isolated from a nine-month-old African baby with abdominal pain, diarrhoea and vomiting. Received from Mr. J. St. A. M. D'Souza, Medical Research Laboratory, Nairobi, Kenya, in 1953.

S. kiambu $\quad 4,12: z: 1,5$

Isolated from a child with pulmonary tuberculosis, who died. The child was resident in Kiambu, in Kenya. Received from Mr. J. St. A. M. D'Souza, Medical Research Laboratory, Nairobi, Kenya, in 1951.

S. kikoma $\quad 16: y: e, n, x \quad$ McAnulty (1958)

Isolated from Zebu cattle faeces in the abattoir at Kampala, the capital of Uganda. Received from Mr. E. McAnulty, Animal Health Research Centre, Entebbe, Uganda, in 1954

*S. kilwa 4,12:1,w:e,n,x Mackey (1955) Isolated from the faeces of an African adult woman. Kilwa is an is land off the coast of Tanganyika. Received from Dr. F. Vivarelli, Medical Research Laboratory, Dar-es-Salaam, Tanzania, in 1953.

S. kinondon $\mathrm{i} \quad 17: a: \mathrm{e}, \mathrm{n}, \mathrm{x} \quad$ Mackey (1955) Isolated from the faeces of an African patient in Kinondoni, a dis- 
Medical Research Laboratory, Dar-es-Salaam, Tanzania, in 1953.
S. Kisarawe
$11: k: e, n, x$
Mackey (1955)

Isolated from an African man with mild enteric fever for two weeks. Kisarawe is a district near Dar-es-Salaam, Tanganyika. Received from Dr. J. P. Mackey, Dar-es-Salaam, Tanzania, in 1951.

*S. klapmuts.

45: $2: z_{39}$

Isolated from a tortolse. Klapmuts is a village in the Western Cape, South Africa. Received from Professor H. D. Brede, Stellenbosch University, South Africa, in 1962.

\section{S. kokomlemle $39: 1, v: e, n, x \quad$ Vella (1958)}

Isolated from a lizard found in Kokomlemle, a district of Accra, Ghana. Received from Major E. E. Vella, Military Hospital, Accra, Ghana, in 1957.

S. korlebu $\quad 1,3,19: 2: 1,5$ Isolated from an African man in Korle-Bu. Received from Dr. F. C. Harris, Medical Research Institute, Accra, Ghana, in 1957.

*S. kraaifontein $\quad 1,13,23: \mathrm{g},(\mathrm{m}), t$ Isolated from a Siamese cat from the village of Kraaifontein, South Africa, Recelved from Professor H. D. Brede, Stellenbosch University, Bellville, C.P., South Africa, in 1962.

*S. kuilsrivier $\quad 1,9,12: \mathrm{g}, \mathrm{m}, \mathrm{s}, \mathrm{t}: \mathrm{e}, \mathrm{n}, \times$ Brede (1963b) isolated from the faeces of a South African infant of the coloured ethnic group. Kuilsrivier is the place of origin in South Africa. Received from Professor H. D. Brede, Stellenbosch University, Bellville, C.P., South Africa, in 1962.

S. kunduchi $\quad 1,4,12,27: 1, z_{28}: 1,2$ Mackey (1955) Isolated from a European man with acute enteritis in Kunduchi, a district near Dar-es-Salaam, Tanganyika. Received from Or. J.P. Mackey, Medical Laboratory, Dar-es-Salaam, Tanzania, in 1951.

S. kuru $6,8: 2: 1, w$ Isolated from cattle in Kuru, the area in which the farm lay. Recelved from Mr. J. Dickson, Veterinary Research Laboratories, Vom, Nigeria, in 1959.

S. labadi $\quad 6,8: \mathrm{d}: z_{6} \quad$ Hughes (1958) Isolated from a woman with diarrhoea and vomiting. Labadi is a vil.. lage on the beach two miles east of Accra, Ghana. Received from Dr. M. H. Hughes, Medical Research Institute, Accra, Ghana, in 1954.

S. lagos $\quad 1,4,12: i: 1,5$ Isolated from a human symptomless excreter in Nigeria. Lagos is the 
Federal capital of Nigeria. Received from Dr. Ade John, Federal Laboratory Service, Yaba, Lagos, Nigeria, in 1963.

S. langford 28:b:e,n, $z_{15}$ Douglas and Taylor (1954) isolated from a tortoise. Langford is a town near Bristol, England. Received from Professor K. E. Cooper, Bristol University, in 1951.

s. legon $4,12: c: 1,5 \quad$ Vella (1958)

Isolated from a lizard caught at Legon Hill near Accra, Ghana, where the university is situated. Received from Major E. E. Vella, Military Hospital, Accra, Ghana, in 1957.

S. leith $6,8: a: e, n, z_{15}$

Isolated from a 52-year-old woman in Leith, a town near Edinburgh, Scotland, Received from Or. R. W. Tonkin, Royal Infirmary, Edinburgh, Scotland, in 1957.

*S. lethe $41: \mathrm{g}, \mathrm{t}$ Isolated from a tortoise. Named after the river of oblivion in Hades. Received from Dr. J. A. Boycott, Public Health Laboratory, Taunton, Somerset, England, in 1952.

*S. limbe $13,22: \mathrm{g}, \mathrm{m}, \mathrm{t}$ of human origin. The patient came from Limbe in Nyasaland. Received from Mr. R. W. Charlton, Blantyre, Nyasaland, in 1962.

* $\underline{\text { S. lincoln }} \quad 11: \mathrm{m}, \mathrm{t}: \mathrm{e}, \mathrm{n}, \mathrm{x}$

Isolated from a woman with food poisoning. This was a school outbreak and approximately 90 people were affected. Lincoln is the county town of Lincolnshire, England. Received from Dr. J. M. Croll, Public Heal th Laboratory, Lincoln, in 1962.

s. lindi 38:r:1,5 Telling, Taylor and Douglas (1951)

Isolated from two adult cases of diarrhoea. One was a European woman and the other an African aged 35 years, with enteritis. Lindi is a town south of Dar-es-Salaam, Tanganyika. Received from Mr. R. C. Telling, Medical Research Laboratory, Dar-es-Salaam, Tanzania in 1949.

\section{*S. lindrick $\quad 9,12: e, n, x: 1,5,7$}

Isolated from two children living in a rural area of Sheffield. The cases appeared to be unrelated and both had gastro-enteritis. Isolated in Carlton-in-Lindrick, a district in Yorkshire, England. Received from Dr. E. H. Gillespie, Public Health Laboratory, Sheffield, England in 1957.

*. L. Iindrick var. 1,7 9,12:e,n,x:1,7

Isolated from a tortoise in South Africa and named S. lindrick var. 1,7 as this isolation was a serological variety of $\mathrm{s}$. lindrick 
9,12:e, $n, x: 1,5,7$. Received from Professor H. D. Brede, Stellenbosch University, South Africa, in 1962.

S. linton 13,23:r:e,n, $z_{15}$ Isolated from a two-year-old boy with gastro-enteritis who became $i 11$ on board ship returning from Kenya. The boy lived in Linton Road, Oxford. Received from Dr. W. H. H. Jebb, Public Health Laboratory, Oxford, England, in 1961.

․ lishabi $\quad(9), 46: z_{10}: 1,7 \quad$ Collard and Sen (1959, 1960b) Isolated from the faeces of a lemur in the Zoo in University College, Ibadan. Named after a street in the campus of the college. Received from Professor P. Collard, University College, Ibadan, Nigeria, in 1957.

S. liverpool $\quad 1,3,19: d: e, n, z_{15}$ Isolated from a male symptomless excreter in Liverpool, a large town in Lancashire, England. Received from Professor D. T. Robinson, Public Health Laboratory, Liverpool, in 1956.

s. livingstone $\quad 6,7: \mathrm{d}: 1, \mathrm{w} \quad$ Picton, Stirrup, Price and Taylor (1953)

Isolated from two adults of an airline staff who were infected either at Victoria Falls or Livingstone. Both suffered from gastro-enteritis. Livingstone is a town in Zambia near Victoria Falls. Received from Dr. W. H. A. Picton, Hillingdon Hospital, Middlesex, England, in 1951.

S. 11 andoff $\quad 1,3,19: z_{29}$

Isolated from a calf with scours by the Veterinary Investigation Centre, Cardiff, South Wales. Received from Mr. W. J. Sojka, Weybridge, Surrey, England, in 1956.

*S. lobatsi $52: 1,5,7$

Isolated from Bechuanaland boneless beef. The beef was prepared at an abattoir in Lobatsi, Bechuanaland. Received from Dr. A. J. H. Tomlinson, Public Health Laboratory, County Hall, London, England, in 1961.

*s. louwbester $\quad 16: z: e, n, x$

Isolated from bovine sources. Received from Dr. H. J. D. Botes, Veterinary Research Laboratory, Onderstepoort, South Africa, in 1963.

*s. luanshya $13,23: \mathrm{g}, \mathrm{s},(\mathrm{t}) \quad$ Edwards, Nicewonger and Tarrant (1957) Isolated from an adult African male in Luanshya, Northern Rhodesia. This serotype resembled $\underline{S}$. okatie but was sufficiently different to 
be published as a separate species. Received from Mr. W. G. Tarrant, European Hospital, Luanshya, Northern Rhodesia, in 1951.

S. luke $\quad 1,47: \mathrm{g}, \mathrm{m}, \quad$ Report (1959) Isolated from bone and meat meal and named after St. Luke's Hospital where the Laboratory is situated in Guildford, Surrey. Received from Dr. G. T. Cook, Public Health Laboratory, St. Luke's Hospital, Guildford, Surrey, England, in 1957.

․‥ luton 60:z:e,n,x Isolated from a thirteen-year-old girl who had recently returned from abroad. Luton is a town in Bedfordshire, England. Received from Dr. H. D. Holt, Public Health Laboratory, Luton, Bedfordshire, in 1962.

S. magumeri $\quad 1,6,14,25: e, h: 1,6$ Collard and Sen $(1960 \mathrm{a}, \mathrm{b})$ Isolated from the intestine of a lizard (Agama agama) in Magumeri, the district of origin in Nigeria. Received from Professor P. Collard University College, Ibadan, Nigeria, in 1958.

S. magwa $21: d: e, n, x$ of human origin, isolated in Magwa, one of the principal settlements in the Kuwait 0 il Company area, Kuwait. Received from Dr. J. Brebner, Kuwait 0 il Company, London, England, in 1955.

S. manchester $\quad 6,8: 1, v: 1,7 \quad$ Taylor and Douglas (1948b) Isolated from the urine of a patient who had been diagnosed as having paratyphoid fever. Manchester is a city in Lancashire where the laboratory is situated. Received from Dr. H. W. Clegg, Public Health Laboratory, York Place, Manchester, England, in 1947. A strain from a patient with severe gastro-enteritis was isolated in Nairobi, Kenya, about the same time.

S. mapo $6,8: z_{10}: 1,5$ Collard and Sen $(1959,1960 \mathrm{~b})$ Isolated from the faeces of a Nigerian child with enteritis in Mapo, a district of Ibadan, Nigeria. Received from Professor P. Collard, University College, Ibadan, Nigeria, in 1957.

S. marylebone $\quad$ (9) $46: k: 1,2 \quad$ Boycott, Taylor and Douglas (1953), Douglas and Taylor (1954)

Isolated from a tortoise (Testudo graeca). Marylebone is a borough of London, England. This serotype was originally published as 9,12: $k: 1,2$ but was later found to have the antigenic structure (9) 46:k:1,2 (Kauffmann 1956). Received from Dr. J. A. Boycott, Public Health Laboratory, Taunton, Somerset, in 1951.

S. maron $\quad 3,10: \mathrm{d}: z_{35}$ isolated from Ceylonese desiccated coconut sampled in Liverpool. 
Imported to England on s.s. Maron. Received from Dr. E. C. Armstrong, Public Health Laboratory, Liverpool, in 1962.

S. mathura (9),46:i:e,n,z, Sharma and Singh (1961a, b) Isolated from cattle in Mathura, a town in India. Received from Or. C. M. Singh, U.P. College of Veterinary Science, Mathura, India, in 1960.

S. matopeni $\quad 30: y: 1,2$ Telling, Taylor and Douglas (1951)

Isolated from an adult African with a typhoid-like illness in Ndoro, Tanganyika. Matopeni was chosen as the name for this serotype as it was a neighbouring district and Ndoro was considered too close to Ndolo which had already, been used to name Salmonella ndolo. Received from Mr. R. C. Telling, Medical Laboratory, Dar-es-Salaam, Tanzania, in 1949.

S. menston $6,7: 9,5, t \quad C o l b e c k$, Douglas and Taylor (1951)

Isolated from two children; the first aged two years, recovering from acute gastro-enteritis; the second, aged 12, with infective endocarditis and gastro-enteritis. Received from Dr. J. C. Colbeck, Public Health Laboratory, Wakefield, Yorkshire, in 1947. 5. menston was isolated from nine patlents, two healthy excretors, three other people, a turkey, and from river water between 1948 and 1950.

*S. merseyside $\quad 16: \mathrm{g}, \mathrm{t}: 1,5$ Isolated from a two-month-old male child with chickenpox and diarrhoea. This serotype was named $\underline{S}$. merseyside as there were further cases and it was found in patients living on both sides of the River Mersey. Received from Dr. E. C. Armstrong, Public Health Laboratory, Liverpool, England, in 1956.

S. mgulani $\quad 38: i: 1,2$ Telling, Taylor and Douglas (1951)

Isolated from the faeces of a European man aged 23 who had gastroenteritls for seven days. The patient was resident at Mgulani Transit Camp, Dar-es-Salaam, Tanganyika, Recelved from Mr. R. C. Telling, Medical Laboratory, Dar-es-Salaam, Tanzania, in 1959.

S. midhurst $\quad 53: 1, z_{28}: z_{39}$

Isolated from maize meal sent from a miller in Midhurst, Sussex, England. Received from Dr. G. T. Cook, Public Health Laboratory, Guildford, Surrey, England, in 1959. 
*S. mj imwema 1,9,12:b:e,n,x Mackey (1955)

Isolated from a European man who had had gastro-enteritis for three days. Mj imwema is a district near Dar-es-Salaam, Tanganyika.

Received from Dr. J. Mackey, Medical Laboratory, Dar-es-Salaam, Tanzania, in 1951 .

*S. mobeni $16: 9, s,(t)$

Isolated from a patient in Mobeni, a suburb of Durban in the Province of Natal, South Africa. The $H$ antigeni structure of $S$. mobeni has been expressed in different ways by different investigators, see Kauffmann (1959.) Kauffmann has adopted the formula $16: g, m, s, t$. The structure 16:g,s, $(t)$ expresses our findings. Received from Dr. M.W. Henning, Veterinary Services, Onderstepoort, South Africa, in 1952.

S. mokola 3,10:y:1,7 Collard and Sen (1959, 1960b)

Isolated from the faeces of a Nigerian adult with dysentery in Mokola, a district of Ibadan, Nigeria. Received from Professor P. Collard, University College, Ibadan, in 1957.
5. molade
(8) $20: z_{10}: z_{6}$
Collard and Sen $(1960 a, b)$

Isolated from the faeces of a Nigerian child with diarrhoea and named after the patient. Received from Professor P. Collard, University College, Ibadan, Nigeria, in 1958.

S. morocco $\quad 30: 1, z_{13}, z_{28}: e, n, z_{15}$

Isolated from bone imported from Morocco. Received from Dr. J. H. C. Walker, Public Health Laboratory, Maidstone, England, in 1958.

s. moroto $28: z_{10}: 1, w \quad M c$ Anulty (1958)

I solated from the faeces of Zebu cattle. Moroto is a town in Uganda.

Received from Mr. E. McAnulty, Animal Health Research Centre, Entebbe, Uganda, in 1956.

*S. mosselbay $\quad 43: \mathrm{g}, \mathrm{s},(\mathrm{t}): \mathrm{z}_{42}$

Isolated from a tortoise (Chersina angulata). Mosselbay is a town and district of South Africa. Received from Professor H. D. Brede, Stellenbosch University, Belliville, C.P., South Africa, in 1963.

s. mount pleasant $\quad 47: z: 1,5$

Isolated from Ceylonese desiccated coconut. Mount Pleasant is the address of the Laboratory. Received from Or. E. C. Armstrong, Public Health Laboratory, 126, Mount Pleasant, Liverpool, England, in 1960.

*S. nairobi 42:r

Isolated from a five-month-old child with mild enteritis, living in Nai robi, Kenya. Received from Mr. J. St. A. M. D'Souza, Medical Research Laboratory, Kenya in 1950. 
*S. namib

$50: g, m, s, t: 1,5$

Isolated from a snake (Psammophis leightoni trinasalis) which is found mostly in the Namib desert. Received from Professor $H$. D. Brede, Stellenbosch University, Bellville, C.P., South Africa, in 1963.

S. nashua $\quad 28: 1, v: e, n, z_{15}$

Isolated from a tortoise and named after an American racehorse.

Received from Dr. J. A. Boycott, Public Health Laboratory, Taunton, Somerset, England, in 1954.

s. nchanga $\quad 3,10: 1, v: 1,2 \quad$ Douglas, Taylor and Fairchild

Isolated from a twenty-three-year-old African man who was a symptomless excreter. Nchanga is the name of a copper mine in the neighborhood of which the patient lived. Received from Mr. L. G. Fairchild, Chingola, Northern Rhodesia, in 1949.

*S. neasden $\quad 9,12: \mathrm{g}, 5, \mathrm{t}: \mathrm{e}, \mathrm{n}, \mathrm{x} \quad$ Douglas, Taylor and McMath

Isolated from a sixteen-month-old boy suffering from diarrhoea and vomiting. The child was in Neasden Hospital. Received from Dr. W. F. T. McMath, Neasden Hospital, London, England, in 1948.

\section{S. new-haw $\quad 3,15: e, h: 1,5$}

Isolated from a turkey poult with enteritis and lung congestion. New Haw is the site of the Laboratory at Weybridge, Surrey, England. Received from Mr. W. J. Sojka, New Haw, Weybridge, Surrey, in 1956.

S. newlands $\quad 3,10: e, h: e, n, x \quad$ Greening, Price and Taylor

Isolated from a sixty-seven-year-old man with a four-day attack of diarrhoea. Newlands is an area of Hull where the general practitioner who sent in the specimen is in practice. Received from Dr. C. L. Greening, Public Health Laboratory Service, Hu11, England, in 1951.

s. nigeria 6,7:r:1,6 Collard and Sen (1958a, 1960b). Isolated from the faeces of a Nigerian child and named after the country. Received from Dr. W. D. Silvera, University College, Ibadan, Nigeria, in 1952.

S. nima 28:y:1,5 Hughes (1958) Isolated from the enlarged mesenteric gland of an African child who died suddenly following a sulpharsphenamine injection for Yaws. Nima is a village on the outskirts of Accra where the patient lived. Received from Dr. M. H. Hughes, Medical Research Institute, Accra, Ghana, in 1953. 
s. norton $\quad 6,7: i: 1, w$

Isolated from a sewer swab from a bacon factory in Norton, a town in Yorkshire, England. Received from Dr. J. H. McCoy, Public Health Laboratory, Kingston-upon-Hull, Yorkshire, in 1961.

s. norwich $\quad 6,7: \mathrm{e}, \mathrm{h}: 1,6 \quad$ Taylor, MacDonald and Sivell (1951)

Isolated from pig mesenteric glands. Norwich is the county town of Norfolk. Received from Dr. A. MacDonald, Public Heal th Laboratory, Norwich, England, in 1945.

S. nottingham $\quad 16: d: e, n, z, 15 \quad$ Ludlam, Taylor and Douglas

Isolated from a nine-year-old boy with enteritis. Nottingham is the county town of Nottinghamshire, England. Received from Or. G. B. Ludlam, Public Health Laboratory, Nottingham, in 1948.

s. nyanza $\quad 11: 2: z_{6}$

Isolated from a thirteen-year-old boy with fever, abdominal pain and cough. The patient was in Bugoma Hospital in the Nyanza district. Received from Mr. J. St. A. M. D'Souza, Medical Research Laboratory, Nairobi, Kenya, in 1960.

s. odozi 30:k:e,n,x,z15 Collard, Sen and Lapage (1962)

Isolated from the faeces of a patient in Odozi, a district in Nigeria. Received from Professor P. Collard, University College, Ibadan, Nigeria, in 1959.

S. offa $\quad 41: z_{38} \quad$ Collard and Sen (1959, 1960b) Isolated from the faeces of a healthy Nigerian adult in Offa, a village north-east of Ibadan, Nigeria. Received from Professor P. Collard, University College, Ibadan, Nigeria, in 1957.

s. okefoko

$$
\begin{aligned}
3,10: c: z_{6} & \text { Collard, Sen and Montefiore } \\
& (1957) . \text { Collard and Sen } \\
& (1958,1960 b)
\end{aligned}
$$

Isolated from the intestine of a rat in Okefoko, a district of Ibadan, Nigeria. Received from Professor P. Collard, University College, Ibadan, Nigeria, in 1956.

s. okerara $\quad 3,10: z_{10}: 1,2 \quad$ Collard and Sen $(1959,1960 \mathrm{~b})$ Isolated from the faeces of a seventeen-year-old Nigerian man with dysentery in Okerara, a district of Ibadan, Nigeria. Received from Professor P. Collard, University College, Ibadan, Nigeria, in 1957. 
S. Omifisan Collard and Sen (1960b) Isolated from the faeces of a Nigerian adult with diarrhoea in Omifisan, a district of Ibadan, Nigeria. Received from Professor P. Collard, University College, Ibadan, Nigeria, in 1956.

S. ona 28:g,s,t Collard and Sen (1958, 1960b) Isolated from a cow in Ona, a district of Ibadan, Nigeria. Received from Professor P. Collard, University College, Ibadan, Nigeria, in 1956.

s. onireke $\quad 3,10: d: 1,7 \quad$ Collard and Sen $(1959,1960 \mathrm{~b})$ Isolated from the faeces of a healthy Nigerian adult in Onireke, a distrlct of Ibadan, Nigeria. Received from Professor P. Collard, University College, Ibadan, Nigeria, in 1958.

s. oritamerin Collard and Sen (1959, 1960b) Isolated from faeces of a European adult with gastro-enteritis in Oritamerin, a district of Ibadan, Nigeria. Received from Professor P. Collard, University College, Ibadan, Nigeria, in 1957.

S. os $9,12: a: 1,6 \quad$ Report (1959)

Isolated from meat and bone meal. The name is derived from os, ossis, Latin, bone. Received from Dr. J. H. C. Walker, Public Health Laboratory, Maidstone, Kent, England, in 1957.

s. oxford 3,10:a:1,7 Jebb, Douglas and Taylor

Isolated from a laboratory guinea pig and named after the county town of Oxfordshire, England. A strain was received about the same time from a snake in the London Zoo. Received from Dr. W. H. H. Jebb, Public Health Laboratory, Oxford, in 1950.

*S. oysterbeds $\quad 6,7: z: z_{42}$ Isolated from a tortoise caught near a coastal strip named Oysterbeds in South Africa. Received from Professor H. D. Brede, Stellenbosch University, Bellville, C.P., South Africa, in 1963.

*S. parow $\quad 3,15: 9, m, s, t$

Isolated from a patient living in Parow, a suburb of Cape Town, South Africa. Received from Professor H. D. Brede, Stellenbosch University, Bellville, C.P., South Africa, in 1962.

S. patience 28:d:e,n,z, 15

Isolated from a tortoise and named after one of the virtues. Recelved from Dr. J. A. Boycott, Public Heal th Laboratory. Taunton. Somerset, England, in 1953.

s. penarth $\quad 9,12: z_{35}: z_{6}$ Isolated from sewage in Penarth, a town in Glamorganshire, South 
Wales. Received from Dr. R. W. S. Harvey, Public Health Laboratory, Cardiff, South Wales, in 1952.

S. plymouth $\quad$ (9), $46: d: z_{6}$

Isolated from a fourteen-year-old boy with colitis. Plymouth is a town in Devonshire, England. Received from Dr. C. H. Jellard, Public Health Laboratory, Plymouth in 1957.

*E. portbech $\quad 42: 1, v: e, n, x, z, 5$

Isolated from Bechuanaland boneless beef. Portbech is a compound name from PORT (of London) BECHuanaland. Received from Dr. B. C. Hobbs, Food Hygiene Laboratory, Colindale, London, England, in 1961.

s. portsmouth $\quad 3,15: 1, v: 1,6 \quad$ Hughes and King (1958) isolated from a man probably infected in Singapore, who had diarrhoea and vomiting on a flight from Singapore to Britain. Named after the site of a laboratory in Hampshire, England. Received from Dr. K. E. A. Hughes, Public Health Laboratory, Portsmouth, in 1957.

S. preston $1,4,12: 2: 1, w$ isolated from the faeces of a man. Preston is a town in Lancashire, England. Received from Dr. A. A. Miller, Royal Infirmary, Preston, in 1954.

S. redhill $11: \mathrm{e}, \mathrm{h}: 1, \mathrm{z}_{13}, \mathrm{z}_{28}$

Isolated from a girl of $7 \frac{1}{2}$-years with diarrhoea and vomiting who had recently returned from Africa by air. She had had two attacks of diarrhoea in Africa. Redhill is a town in Surrey, England and the site of the hospital. Received from Or. J. K. Carter, County Hospital, Redhill, Surrey, in 1956.

S. redlands $\quad 16: z_{10}: e, n, z_{15}$ Isolated from a nine-year-old boy with vomiting, living in the Sheffield area, who attended the Redlands School, Worksop. Received from Dr. E. H. Gillespie, Public Health Laboratory, Sheffield, England, in 1958.

S. remo $\quad 1,4,12,27: r: 1,7$ Collard, Sen and Lapage (1962) Isolated from human faeces in Remo, a town in Western Nigeria. Received from Professor P. Collard, University College, Ibadan, Nigeria, in 1959.

S. ridge $9,12: c: z_{6}$ Hughes (1958) Isolated from a European woman with fever and diarrhoea. "The Ridge" was the European quarter of Accra. Received from Dr. M. H. Hughes, Medical Research Institute, Accra, Ghana, in 1954.

S. roan $38: 1, v: e, n, x$ Isolated from a two-month-old European child with diarrhoea and 
vomiting. Named after the Roan copper mines. Received from Mr. W. G. Tarrant, European Hospital, Luanshya, Rhodesia, in 1955.

*S. roggeveld $\quad 51: 1,7$

Isolated from a tortoise in Roggeveld, a place in Namaqualand in

South Africa. Received from Professor H. D. Brede, Stellenbosch University, Bellville, C.P., South Africa, in 1962.

*S. rowbarton $\quad 16: \mathrm{m}, \mathrm{t} \quad$ Boycott, Taylor and Douglas (1953), Douglas and Taylor (1954)

Isolated from a tortoise. Rowbarton is a place near Taunton, Somerset, England. Received from Dr. J, A. Boycott, Public Health Laboratory, Taunton, in 1951.

S. ruiru $21: y: e, n, x \quad$ Lapage and Taylor (1964) I solated from a woman living in Ruiru, a suburb of Nairobi, Kenya. Received from Dr. E. R. N. Cooke, Medical Research Laboratory, Nai robi, in 1955.

S. saka 47:b Collard and Sen (1960a) I solated from human faeces. Received from Professor P. Collard, University College, Ibadan, Nigeria, in 1958.

s. salford 16:l,v:e,n,x Douglas, Taylor, Greenwood and Ibbotson (1951)

Isolated from a four-month-old boy with acute gastro-enteritis. The child was in Hope Hospital, Salford, a town in Lancashire, England. Received from Dr. E. Greenwood, Hope Hospital, Salford, in 1948.

S. sarajane $\quad 4,12,27: d: e, n, x \quad$ Douglas and Taylor (1954) Isolated from a tortoise which was called Sara Jane. Received from Dr. M. Pownall, Public Health Laboratory, Sheffield, in 1951.

S. sekondi $\quad 3,10: e, h: z_{6}$ Isolated from an airman in Ghana. Sekondi is a town in Ghana. Received from Dr. F. E. Lipscomb, R.A.F., Aylesbury, Buckinghamshire England, in 1962.

S. Seremban $9,12: i: 1,5 \quad$ Frisby and Hollos (1954) Isolated from several patients with food poisoning at Seremban, a town in Malaya, Received from Major B. R. Frisby, The David Bruce Laboratories, East Everlelgh near Marlborough, Wiltshire, England, in 1952.

S. Shamba $16: c: e, n, x$ Isolated from an African gardener who was a symptomless excreter. The name is derived from shamba, garden. Received from Dr. E. R. N. 
Cooke, Medical Research Laboratory, Nairobi, Kenya, in 1953.

S. sheffield $38: c: 1,5$

Isolated from the faeces of a seven-month-old boy. Sheffield is a town in Yorkshire, England. Received from Dr. M. Pownall, Public Health Laboratory, Sheffield in 1953.

S. shipley $\quad$ (8) $20: b: e, n, z_{15}$

Isolated from a man in Shipley, a town in Yorkshire, England. Received from Dr. A. J. H. Tomlinson, Public Health Laboratory, Bradford, Yorkshire, in 1951.

S. shoreditch $\quad$ (9), $46: r: e, n, z_{15}$

Isolated from a woman in Shoreditch, a district of London, England. Received from Dr. E. Bailey, The Southern Group Laboratory, Hither Green Hospital, London, in 1945. The original antigenic structure of this serotype was given as $9,12: r: e, n, z_{15}$ but later was found to be

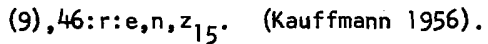

S. shubra $\quad 4,5,12: z: 1,2$ Isolated from the faeces of a 35-year-old East African man with enteritis. Six months later he developed cholecystitis and $\underline{s}$. shubra was isolated from his gall bladder. Shubra is the name of a hlll in Fayid, Egypt. Received from Dr. J. Nagington, Central Medical. Laboratory, Fayid, Egypt, in 1952.

*S. Sofia 4,12:b Boycott, Taylor and Douglas (1953)

Isolated from a tortoise (Testudo graeca) in 1951. At that time the organism was classified as a paracolon bacillus as it fermented salicin and liquefied gelatin. Wesselinoff and Dimow (1964) isolated an identical organism from the faeces of a hedgehog and Kauffmann proposed the name Salmonella sofia for this serotype. Sofia is the capital of Bulgaria. Received from Dr. J. A. Boycott, Public Health Laboratory, Taunton, Somerset, England, in 1951.

S. souza 3,10:d:e,n,x

Isolated in Nairobi, Kenya, from human origin and named after the bacteriologist who isolated it. Received from Mr. J. St. A. M. D' Souza, Medical Research Laboratory, Nairobi, in 1951.

kS. stellenbosch $1,9,12: 2: 1,7 \quad$ Brede $(1960,1961 \mathrm{a})$

Isolated from the faeces of a 38-year-old coloured man who had severe diarrhoea for two months and came from the environment of Stellenbosch, the site of the University. Received from Professor H. D. Brede, Stellenbosch University, Bellville, C.P., South Africa, in 1960. 
*.S. stevenage $\quad 1,13,23: z_{42}: 1,7$

Isolated from a one-year-old boy with gastro-enteritis and named after a town in Hertfordshire, England. Received from Dr. H. D. Holt, Public Health Laboratory, Luton, Bedfordshire, in 1962.

*s. stikland $\quad 3,10: m, t: e, n, x$

Isolated from the faeces of a six-month-old child with chronic gastroenteritis. Stikland is the name of the community in South Africa from which the child came. Received from Professor H. D. Brede, Stellenbosch University, Bellville, C.P., South Africa, in 1963.

S. stourbridge $\quad 6,8: b: 1,6$

Isolated from a three-year-old boy and a 56-year-old woman who were both being treated in Wordsley Hospital where the child was in a ward and the woman was an out-patient. No other connection between these two patients was demonstrated. Wordsley Hospital is near Stourbridge, Worcestershire, in England. Received from Dr. B. R. Sandiford, Public Health Laboratory, Birmingham, England, in 1960.

s. suberu $\quad 3,10: \mathrm{g}, \mathrm{m} \quad$ Collard and Sen $(1960 \mathrm{a}, \mathrm{b})$ Isolated from the faeces of a Nigerian adult with dysentery. Named after the patient. Received from Professor P. Collard, University College, Ibadan, Nigeria, in 1958.

*E. Sullivan $\quad 6,7: z_{42}: 1,7$

Isolated from the same sample of South African frozen egg as $\underline{s}$.

gilbert. They were named together. Sullivan was the composer who wrote the music for Gilbert's librettos. Received from Dr. W. H. H. Merivale, Guy's Hospital, London, England, in 1960.

s. surat $\quad 1,6,14,25: r(i): e, n, z_{15}$ Isolated from Chinese frozen whole egg imported on s.s. Surat. Recelved from Dr. M. T. Parker, Public Health Laboratory, Manchester, England, in 1956.

s. takoradi $\quad 6,8: i: 1,5 \quad$ Rewell, Taylor and Douglas

Isolated from an immature female python (Python sebae) in the London Zoo. The snake was captured in Takoradi, a town in Ghana. Received from Dr. R. E. Rewell, Zoological Gardens, London, England, in 1946.

S. tamale (8), 20: $z_{29} \quad$ Vella (1958)

Isolated from a lizard in Tamale, a place in Ghana. Received from Major E. E. Vella, Military Hospital, Accra, Ghana, in 1957.

S. tarshyne $\quad 9,12: d: 1,6$

Isolated from a woman in Tarshyne, a residental area of Aden. 
Received from Dr. F. E. Lipscomb, R.A.F. Halton, Buckinghamshire, England, in 1962.

S. taunton

28:k:e, $n, x$

Boycott, Taylor and Douglas

(1953), Douglas and Taylor

(1954)

Isolated from a tortoise (Testudo graeca) in Taunton, a town in Somersetshire. Received from Dr. J. A. Boycott, Public Health Laboratory, Taunton, Somersetshire, England, in 1951.

S. teddington $\quad 4,12,27: y: 1,7$ Isolated from a three-year-old girl with diarrhoea and pyrexia, living in Teddington, Middlesex, England. Received from Dr. L. Cann, Ashford Hospital, Middlesex, in 1955.

S. teko

$$
1,6,14,25: d: e, n, z_{15}
$$

Isolated from a mouse and named after Teko, where the laboratory is

situated. Received from Mr. V. A. Clarke, Veterinary Research Laboratory, Teko, Sierra Leone, in 1955.

\section{S. tel-el-kebir $\quad 13,23: \mathrm{d}: \mathrm{e}, \mathrm{n}, \mathrm{z}_{15}$}

Isolated from the urine of a Mauritian food handler suffering from pyelitis in Tel-el-Kebir, a village in Egypt. Received from Dr. J. F. Watkins, Central Medical Laboratory, Fayid, Egypt, in 1951.

S. teshie $\quad 1,47: 1, z_{13} ; z_{28}: e, n, z_{15}$ Vella (1958)

Isolated from a lizard in Teshie, a place in Ghana. The original culture had the antigenic structure $47: 1, z_{13}, z_{28}: e, n, z_{15}$. Received from Major E. E. Vella, Military Hospital, Accra, Ghana, in 1957. A later isolation had the antigenic structure $1,47: 1, z_{13}, z_{28}$ : e, $n, z_{15}$ (Kauffmann 1961b).

*․․ tosamanga $6,7: z: 1,5$ Mackey (1955)

This strain was from a patient in Tosamanga, a village in the Iringa district of Tanganyika. Received from Dr. J. Mackey, Medical Laboratory, Dar-es-Salaam, Tanzania, in 1953.

S. treforest $\quad 1,51: 2: 1,6 \quad$ Harvey and Price (1962) Isolated from Indian bonemeal and named after the Treforest Chemical Company. The original isolation had the antigenic structure 51:z: 1,6. Received from Dr. R. W. S. Harvey, Public Health Laboratory, Cardiff, South Wales, in 1958. A later isolation, identified by Professor Kauffmann in 1960, had the antigenic structure 1,51:z,1,6 (Kauffmann 1961b).

S. tudu

$$
4,12: z_{10}: 1,6 \quad \text { Hughes (1958) }
$$

I solated from a European woman in Tudu, a suburb of Accra, Ghana. 
Recelved from Dr. M. H. Hughes, Medical Research Institute, Accra, Ghana, In 1954.

S. umbilo $28: z_{10}: e, n, x$

Isolated from a patient in Umbilo, Natal, South Africa. Received from Dr. J. C. Thomas, Central Pathological Laboratory, Durban, Natal, in 1953.

s. umhlali $6,7: a: 1,6$

Isolated from a patient in Umhlali, Natal, South Africa. Received from Dr. J. C. Thomas, Central Pathological Laboratory, Durban, Natal, in 1953.

S. umhlatazana $\quad 35: a ; e, n, z_{15}$

Isolated from a patient in Umhlatazana, Natal, South Africa. The original isolation was monophasic and had the antigenic structure 35:a. Received from Dr. J. C. Thomas, Central Pathological Laboratory, Durban, Natal, in 1953. A diphasic strain with the antigenic structure 35:a:e,n, $z_{15}$ was later isolated in Kuwait. Received from Dr. J. Brebner, Kuwait 0 il Company, in 1955.

*. uphill 42:b:e,n,x,z, Boycott, Taylor and Douglas (1953), Douglas and Taylor

Isolated from a tortoise (Testudo graeca) and named after Uphi11, a suburb of Weston-super-Mare, Somersetshire, England. This serotype was originally published as $42: b: e, n, z_{15}$ and later corrected in a publisher's corrigendum slip to $42: b: e, n, z_{15}, z_{16}$. Kauffmann (1954) gave the antigenic structure as $42: b: e, n$ but in 1957 published it as 42:b:e,n, $z_{15}$ (Kauffman 1957). Later Kauffmann (1959) modified it to 42:b:e, $n, x, z_{15}$ as agglutination with an absorbed $x, z_{16}$ serum is denoted by the symbol " $x$ " in the Kauffmann White scheme. Received from Dr. J. A. Boycott, Public Health Laboratory, Taunton, Somerset, in 1951.

S. uzaramo $\quad 1,6,14,25: z_{4}: z_{24}$ Telling, Taylor and Douglas

Isolated from a young African adult with an enteric-like illness in Uzaramo, a district of the Eastern Province of Tanganyika. Received from Mr. R. C. Telling, Medical Research Laboratory, Dar-es-Salaam, Tanzania, in 1949.

s. vellore $\begin{aligned} 1,4,12,27: z_{10}: z_{35} & \text { Agarwal, Lapage, Bhat and } \\ & \text { Shrivastav (1964) }\end{aligned}$

Isolated from the faeces of a three-year-old girl with diarrhoea 
and kwashlorkor. Vellore is a large town in India. Received from Dr. S. C. Agarwal, Central Research Institute, Kasauli, India, in 1963.

*S. verity $17: e, n, x, z_{15}: 1,6$ Isolated from a tortoise and named after one of the virtues. The antigenic structure of this serotype was given as $17: e, n, z_{15}: 1,6$ (Kauffmann 1957) but later expressed as $17: e, n, x, z_{15}: 1,6$ (Kauffmann 1959) as it possessed the antigen $z_{16}$ and agglutination with an absorbed $x, z_{16}$ serum is denoted by the symbol " $x$ " in the Kauffmann White scheme. Received from Dr. J. A. Boycott, Public Health Laboratory, Taunton, Somerset, England, in 1953.

\section{S. victoria $1,9,12: 1, w: 1,5$}

Isolated from a specimen of subdural haematoma fluid taken from a child. It was not isolated from previous and subsequent specimens of the fluid. Victoria is the town in which the laboratory is situated. Received from Dr. G. N. Cooper, Public Health Laboratory, Victoria, Australia, in 1954.

s. victoriaborg $17: c: 1,6 \quad$ Hughes (1958) Isolated from a one-year-old European girl with febrile diarrhoea. Victoriaborg is a quarter of Accra. Received from Dr. M. H. Hughes, Medical Research Institute, Accra, Ghana, in 1954.

S. vom $\quad 4,12,27: 1, z_{13}, z_{28}: e, n, z_{15}$ Collard and Sen (1960b)

Isolated from an ox with diarrhoea in Vom, a town in Northern Nigeria. Received from Mr. W. Plowright, Veterinary Research Laboratory, Vom, Nigeria, in 1955.

*S. vredelust $\quad 1,13,23: 1, z_{28}: z_{42}$

Isolated from a grey dune mole (Bathyergus suillus). Vredelust is the name of the estate on which the mole was caught. Received from Professor H. D. Brede, Stellenbosch University, Bellville, C.P., South Africa, in 1963.

*S. vrindaban 45: $a: e, n, x$ Makholia and Singh (1963) Isolated from pig faeces in Vrindaban, a town in India. Received from Dr. C. M. Singh, U.P. College of Veterinary Science, Mathura, India in 1962. The biochemical reactions of this strain are not typical of sub-genus 1, II or III, Kauffmann (1963a), but it is classified in sub-genus 11 (Kauffmann (1963b).

s. wandsworth $39: b: 1,2$ Isolated from egg albumen in Wandsworth, a borough of London, 
England. Received from Dr. E. M. Mackay-Scollay, Public Health Laboratory, County Ha11, London, in 1955.

s. warragul $\quad 1,6,14,25: 9, m$

Isolated from a woman in Warragul, a small town in Victoria,

Australia. Received from Mr. G. N. Cooper, Public Health Laboratory, Victoria, Australia, in 1954.

S. wentworth $\quad 11: z_{10}: 1,2$ Isolated from a patient. Wentworth is a place in South Africa where the laboratory is situated. Received from Dr. J. C. Thomas, Central Pathological Laboratory, Durban, Natal, South Africa, in 1953.

s. weston 16:e,h:z6 Boycott, Taylor and Douglas (1953), Douglas and Taylor (1954)

Isolated from a tortoise (Testudo graeca). Weston-super-Mare is a town in Somerset, England. Received from Dr. J. A. Boycott, Public Heal th Laboratory, Taunton, Somerset, in 1951.

S. westphalia $\quad 35: z_{4}, z_{24}$

The strain was isolated in Kaduna, Nigeria, from a patient who had recently arrived from Westphalia, Germany. Received from Major $M$. M. Munro, The David Bruce Laboratories, East Everleigh, Marlborough, Wiltshire, England, in 1960.

S. weybridge $\quad 3,10: d: z_{6}$ Isolated from a turkey. Weybridge is a town in Surrey, England, and the site of a laboratory. Received from Mr. W. J. Sojka, Central Veterinary Laboratory, New Haw, Weybridge, Surrey, in 1954.

*. winchester $\quad 3,10: z_{39}: 1,7$

Isolated from an adult, recently returned from Durban, South Africa. Winchester is the county town of Hampshire, England, and the site of the Laboratory. Received from Dr. M. H. Hughes, Public Health Laboratory, Winchester, in 1959.

s. wingrove $6,8: \mathrm{c}: 1,2$ Isolated from an eighteen-year-old woman living in Wingrove, a district of Newcastle. Received from Dr. R. Norton, Public Health Laboratory, Newcastle-upon-Tyne, England, in 1961.

s. womba $\quad 4,12,27: c: 1,7$ Isolated from a patient in Nigeria. Received from Major J. C. Crook, The David Bruce Laboratories, East Everleigh, Marlborough, Wiltshire, England, in 1953. 
* . woodstock $\quad 16: z_{42}: 1,(5) .7$ Brede $(1961 \mathrm{~b}, \mathrm{~d})$

From the faeces of an eighteen-year-old training nurse with dysentery in Woodstock, a suburb of Cape Town, South Africa where the disease was probably contracted. Received from Professor H. D. Brede, Stel lenbosch University, Bellville, C.P.. South Africa, in 1960.

*S. wynberg $1,9,12: z_{39}: 1,7$

Isolated from the urine of a patient in Wynberg, a suburb of Cape Town, South Africa. Received from Professor H. D. Brede, Stellenbosch University, Bellville, C.P., South Africa, in 1962.

S. yaba $\quad 3,10: b: e, n, z_{15} \quad$ Collard and Sen $(1960 a, b)$ Isolated from the faeces of a Nigerian man in Yaba, an area of Lagos, Nigeria. Received from Professor P. Collard, University of I badan, Nigeria, in 1958.

S. yalding $\quad 1,3,19: p: e, n, z_{15}$ Report (1959) Isolated from bone and meat meal. Yalding was the birthplace of the technician who isolated the strain. Received from Dr. J. H. C. Walker, Public Health Laboratory, Maidstone, Kent, England, in 1957.

S. zadar (9), 46:b:1,6

Isolated from a tortoise. Zadar is a town in Yugoslavia. Received from Dr. J.A. Boycott, Public Health Laboratory, Taunton, Somerset, England, in 1959.

\section{REFERENCES}

Agarwal, S. C., S. P. Lapage, Prema Bhat and J. B. Shrivastav. 1964. A new Salmonella species, Salmonella vellore $\left(1,4,12,27: z_{10}: z_{35}\right)$. J. Path. Bact. 87: 440-441.

Alexander, J. G., S. Hilda Douglas and Joan Taylor. 1954. A new Salmonella species $(X V 1: b: 1,2)$ isolated from a baby. Mon. Bull. Minist. Hlth Lab. Serv. 13:117.

Anderson, E. S., H. J. Anderson and Joan Taylor. 1947. A new Salmonella, Salmonella fayed which caused fatal endocarditis in man. J. Path. Bact. 59:533-537.

Boycott, J. A., Joan Taylor and S. Hilda Douglas. 1953. Salmonella in tortoises. J. Path. Bact. 65:401-411. (and corrigendum). Brede, H. D. 1960. Salmonella stellenbosch, ein neuer Serotyp. $(1,9,12: z: 1,7)$. Zbl. Bakt. I Abt. Orig. 181:415-416. - 1961a. Salmonella stellenbosch. 'N nuwe Serotipe.

S. Afr. med. J. 35:267-268. - 1961b. Salmonella woodstock. IN nuwe Serotipe [16: $\mathbf{z}_{42}$ :

$1,(5), 7]$. S. Afr. med. J. 35:556. 
. 196ic. Salmonella bellville. 'N verdere nuwe Serotipe

$(16: e, n, x: 1,7)$. S. Afr. med. J. $35: 768$.

- 1961d. Salmonella woodstock, ein neuer Serotyp. (16: $z_{42}$ :

1, (5),7). Zbl. Bakt. 1 Abt. Orig. 182:279-280.

- 196le. Salmonella bellville, ein neuer Serotyp. (16:e,n,

$x: 1,7)$. Zbl. Bakt. I Abt. Orig. 183:417-418.

- 1962a. Une nouvelle espece de Salmonella en provenance

de'Afrique du Sud: Salmonella caledon $(4,12: g, m: e, n, x)$. Ann. Inst.

Pasteur. 103: 933-934.

1962b. Salmonella elsiesrivier, a new serotype $\left(16: z_{42}\right.$ :

1,6). J. Bact. 83:1164-1165.

1962c. Salmonella ceres 28:z:z $z_{39}$, eine neue Salmonella

species. Zbl. Bakt. I Abt. Orig. 187:261-262.

- 1963a. Salmonella calvinia: $6,7: a: z_{42}$, eine neue Salmon-

ella species. Zbl. Bakt. I Abt. Orig. 188:137-138.

- 1963 b. Salmonella kuilsrivier $1,9,12: \mathrm{g}, \mathrm{m}, \mathrm{s}, \mathrm{t}: \mathrm{e}, \mathrm{n}, \mathrm{x}$, eine

neue Salmonella species. Zbl. Bakt. I Abt. Orig. 189:115-116.

- 1964a. Salmonella grabouw $11: 9, \mathrm{~m}, \mathrm{~s}, \mathrm{t}: \mathrm{z}_{39}$, a new species.

J. Bact. 87:479-480.

- 1964b. Salmonella chersina: 47:z:z6, a new serotype.

J. Bact. 88:536-537.

Browning, P. M. H., J. M. Moore and J. S. Stevenson. 1959. A new

Salmonella type. (Salmonella glasgow). J. Path. Bact, 77:650-651.

Colbeck, J. C., S. Hilda Douglas and Joan Taylor. 1951. A new

Salmonella type: Salmonella menston. J. Path. Bact. 63:754-755.

Collard; P. and D. Montefiore. 1956. Agama agama as a reservoir of

Salmonella infection in lbadan. W. Afr. med. J. 5:154-156.

, R. Sen and D. Montefiore. 1957. Isolation of salmonellae

from rats in Ibadan. W. Afr. med. J. 6: $: 113-116$.

, and 1958a. Salmonellae isolated from man in

Ibadan. W. Afr. med. J. 1:91-96.

and _ـ_ 1958b. Salmonella type isolated in Ibadan,

Nigeria. Trans. R. Soc. trop. Med. Hyg. 52:283-287.

and - 1959. Salmonellae isolated at Ibadan.

(Second report: Strains isolated during 1957). W. Afr. med. J. 8: $114-116$.

and - 1960a. Salmonellae isolated at Ibadan.

(Third report: Strains isolated during 1958). W. Afr. med. J. 9: $172-174$. 
and - 1960b. Serotypes of Salmonella at Ibadan, Nigeria with special note of the new serotypes isolated in Nigeria. J. Infect. Dis. 106:270-275. and S. P. Lapage. 1962. Salmonella isolated at Ibadan. (Fourth report: Strains isolated during 1959). W. Afr. med. J. 11:77-79.

Datta, S. K. and C. M. Singh. 1964. Salmonella gokul, a new serotype from pigs. Int. Bull. Bact. Nomencl. 14:161-163.

Douglas, S. Hilda and Joan Taylor. 1954. Nine new Salmonella species isolated from imported tortoises. Mon. Bull. Minist. HIth. Lab. Serv. 13:158-162.

, Joan Taylor and L. G. Fairchild. 1953. Two new Salmonella species isolated in Northern Rhodesia, Salmonella nchanga and Salmonella chingola. S. Afr. med. J. 27:404-405. , E. Greenwood and S. Ibbotson. 1951. Human infection due to a new Salmonella, Salmonella salford. Mon. Bull. Minist. H1th. Lab. Serv. 10:75-76. and W. F. T. McMath. 1951. A new Salmonella type isolated from a baby, Salmonella neasden. Mon. Bull. Minist. H1th. Lab. Serv. 10:250-251.

Edwards, P. R., C. R. Nicewonger and W. G. Tarrant. 1957. Two new Salmonella serotypes: Salmonella luanshya and Salmonella okatie. Mon. Bull. Minist. HIth. Lab. Serv. 16:90.

Frisby, B. R. and D. Hollos. 1954. A new Salmonella type. Salmonella seremban. J. R. Army med Cps 100:55-56.

Grant, L. S. 1958. A new Salmonella type: Salmonella jamaica: 9, 12: $r-1,5$. W. Ind. med. J. 7:249-250.

Greening, G., Audrey Price and Joan Taylor. 1953. A new Salmonella type isolated from an adult male with diarrhoea. Salmonella newlands. Mon. Bull. Minist. Hith. Lab. Serv. 12:89-90.

Greenwood, E., A. Powis, S. Hilda Douglas and Joan Taylor. 1953. A new Salmonella type of human origin - Salmonella bolton. Mon. Bull. Minist. Hlth. Lab. Serv. 12:29.

Harvey, R. W. S. and T. H. Price. 1962. Salmonella serotypes and Arizona paracolons isolated from Indian crushed bone. Mon. Bull. Minist. Hlth. Lab. Serv. 21:54-57. Hofmann, S., F. Kauffmann and W. Anz. 1960. Eine neue Salmonella species: Salmonella bornum $=6,(7),(14): z_{38}$ : - und eine neue Salmonella-0-untergruppe (C 4). Zbl. Bakt. I Abt. Orig. 179:39-42. 
Hughes, M. H. 1955. Enteric fevers and normal Salmonella agglutinins in the Gold Coast. J. Hyg. Camb. 53:368-378.

1958. Salmonella infections in Accra, Ghana, West Africa.

Trans. R. Soc. Trop. Med. Hyg. 52:377-382.

Hughes, K. E. A., and G. J. G. King. 1958. A new Salmonella serotype:

Salmonella portsmouth. Mon. Bull. Minist. Hlth. Lab. Serv. 17:

178-179.

Jebb, W. H, H., S. Hilda Douglas and Joan Taylor. 1951. A new Salmon-

ella type. Salmonella oxford, isolated from a guinea pig. Mon.

Bull. Minist. HIth Lab. Serv. 10:200-201.

Kauffmann, F. 1954. Enterobacteriaceae. Munksgaard, Copenhagen.

- 1956. A new Salmonella 0-subgroup $=(9), 46$. Acta. path.

microbiol. scand. 38:69-70.

- 1957. Das Kauffmann-White Schema. Ergeb. mikrobiol.

Immun. Forsch. exp. Ther. 30:160-216.

- 1958a. On the biochemical behaviour of new Salmonella

types. Acta. path. microbiol. scand, 43:175-184.

- 1958b. Supplement to the Kauffmann-White Scheme (1).

Acta. path. microbiol. scand. 43:247-253.

- 1959. Supplement to the Kauffmann-White Scheme (11).

Acta. path. microbiol. scand. 45:411-416.

- 1960a. Supplement to the Kauffmann-White Scheme (1II).

Acta. path. microbiol. scand. 49:89-94.

- 1960b. Two biochemical subdivisions of the genus Salmon-

ella. Acta. path. microbiol. scand. 49:393-396.

- 196la. Supplement to the Kauffmann-White Scheme (IV).

Acta. path. microbiol. scand. 52:221-226.

- 196lb. Die Bakteriologie der Salmonella-species p.86 and

p.106. Munksgaard, Copenhagen.

- 1962. Supplement to the Kauffmann-White Scheme (V).

Acta. path. microbiol. scand. 55:349-354.

1963a. Zur differential diagnose der Salmonella subgenera

1, 11, and III. Acta. path., microbiol. scand. 58:109-113.

- 1963b. Supplement to the Kauffmann-White Scheme (VI).

Acta. path. microbiol. scand. 58:339-347.

- 1964a. Weitere Salmonella species des subgenera 11 (1963).

Acta. path. microbiol. scand. 61:579-582.

- 1964b. Supplement zum Kauffman-White Schema (VII). Acta.

path. microbiol. scand. 61:583-587. 
Kelterborn, E. 1961. Über den Aufbau einer Salmonella-Kartei mit Kerblochkarten. Zbl. Bakt. I Abt. Orig. 183:473-484.

Lapage, S. P. and Joan Taylor. 1964. The incidence and description of Salmonella ruiru. J. comp. Path. 74:320-321.

Ludlam, G. B., Joan Taylor and S. Hilda Douglas. 1953. A new Salmonella type of human origin: Salmonella nottingham. Mon. Bull. Minist. H1th. Lab. Serv. 12:29-30.

MacDonald, A., C. W. Sivell, W. R. Emms and S. Hilda Douglas. 1948. A new type of Salmonella isolated from shellfish: Salmonella brancaster. Mon. Bull. Minist. Hlth. Lab. Serv. 2:158-159. Mackey, J. 1955. Salmonellosis in Dar-es-Salaam. E. Afr. med. J. 32: 1-6.

McAnulty, E. 1958. Salmonellae in Uganda. Nature, Lond. 181:576. Makholia, B. 0., and C. M. Singh. 1963. Salmonella vrindaban, a new and atypical serotype from pig. Int. Bull. Bact. Nomencl. 13: 177-178.

Mbbius, L. and C. Tauchnitz. 1961. Über eine im Bezirk Leipzig neu aufgetretene Salmonella species $4,12: z_{10}: e, n, x$. Zbl. Bakt. I Abt. orig. 181:281-282.

Picton, W. H. A., W. Stirrup, Audrey Price and Joan Taylor. 1953. A new Salmonella type, Salmonella livingstone. J. Path. Bact. 66: 310-312.

Price, Audrey U. and H. D. Holt. 1955. A new Salmonella serotype, Salmonella colindale of human origin. Int. Bull. Bact. Nomencl. $5: 1-3$.

Reid, J. D., Jennifer Stitt and Joan Taylor. 1956. A new Salmonella serotype. Salmonella freetown $(38: y: 1,5)$. Int. Bull. Bact.

Nomenc 1. 6:61-62.

Report of a working party of the Public Health Laboratory Service 1959. Salmonella organisms in Animal Feeding Stuffs and Fertilizers. Mon. Bull. Minist. HIth. Lab. Serv. 18:26-35.

Report of a working party of the Public Health Laboratory Service 1961. Salmonella organisms in Animal Feeding Stuffs. Mon. Bull. Minist. Hlth. Lab. Serv. 20:73-85.

Rewell, R. E., Joan Taylor and S. Hilda Douglas. 1948. A new Salmonella type Salmonella takoradi isolated from a python. Mon. Bull. Minist. H1th. Lab. Serv. 7:266-267.

Sharma, V. K. and C. M. Singh. 196la. Occurrence of Salmonellae in domestic animals and poultry in India. Nature, Lond. 191:622-623. 
and 1961b. Occurrence of Salmonella sp. in

poultry and domestic animals. Indian J. Microbiol. 1:119-122. and - 1963. Salmonella brijbhumi, a new serotype

from sewage. Int. Bull. Bact. Nomencl. 13:179-180.

Stevenson, J. S. 1953. A new Salmonella type. Salmonella ibadan. J. Path. Bact. 66:574-575.

Stitt, Jennifer and T. Walsh. 1956. A new Salmonella serotype, Salmonella bury: $4,27,12: c-z_{6}$ of human origin. Int. Bull. Bact. Nomencl. 6:51-52.

Story, P., S. Hilda Douglas and Joan Taylor. 1952. A new Salmonella type isolated from a baby: Salmonella clerkenwell. Mon. Bull. Minist. Hlth. Lab. Serv. 11:22-23.

Taylor, Joan and S. Hilda Douglas. 1948a. Salmonella birkenhead. A new Salmonella type causing food poisoning in man. J. Clin. Path. $\underline{1: 237 .}$ and 1948b. A new Salmonella type, Salmonella manchester. Mon. Bull. Minist. HIth. Lab. Serv. 7:117-118. , W. Hayes, J. Freeman and E. S. Anderson. 1948. A new Salmonella type: Salmonella chittagong. J. Path. Bact. 60:35-42. , S. P. Lapage, Margaret M. Brookes, G. J. G. King, D. J. H. Payne, B. R. Sandiford and J. S. Stevenson. 1965. Salmonella serotypes identified at the Salmonel la Reference Laboratory, Colindale, from 1951-1963. Mon. Bull. Minist. Hlth. Lab. Serv. 24: 164-229; 236-277.

A. McDonald and C.W. Sivel1. 1951. A new type of Salmonella isolated from porcine lymph nodes: Salmonella norwich. Mon. Bull. Minist. Hith. Lab. Serv. 10:76.

Telling, R. C., Joan Taylor and S. Hilda Douglas. 1951. Four new Salmonella types from human sources in Tanganyika Territory. Mon. Bull. Minist. Hith. Lab. Serv, 10:251-255.

Vella, E. E. 1958. Salmonellosis in lizards of Ghana. J. R. Army med. Cps. 104:236-237.

Waite, Joan, Joan Taylor and E. N. Davey. 1957. A new Salmonella serotype. Salmonella gloucester. Mon. Bull. Minist. Hith. Lab. Serv. 16:14-16.

Watkins, J. F., S. Hilda Douglas and Joan Taylor. 1955. A new Salmonella serotype, Salmonella deversoir isolated from human faeces. Int. Bull. bact. Nomencl. 5:5-6. 
Wesselinoff, W. and I. Dimow. 1962. Eine neue Salmonella-species Salmonella sofia. 4,12:b: -. Zbl. Bakt. I Abt. Orig. 187:263265.

Wilson, H. M., Joan Taylor and E. S. Anderson. 1947. A new type of Salmonel la - Salmonella cambridge. Mon. Bull. Minist. Hlth. Lab. Serv. $6: 135-136$. 
